Article

\title{
Preparation and Characterization of a Novel Activated Carbon@Polyindole Composite for the Effective Removal of Ionic Dye from Water
}

\author{
Bushra Begum ${ }^{1,2, *(\mathbb{D})}$, Saba Ijaz ${ }^{1}$, Rozina Khattak ${ }^{1, *(D)}$, Raina Aman Qazi ${ }^{1}$ (D), Muhammad Sufaid Khan ${ }^{3}$ \\ and Khaled H. Mahmoud ${ }^{4}$ \\ 1 Department of Chemistry, Shaheed Benazir Bhutto Women University, Peshawar 25000, Pakistan; \\ sabaijaz240@gmail.com (S.I.); rainaaman@sbbwu.edu.pk (R.A.Q.) \\ 2 National Centre of Excellence in Physical Chemistry, University of Peshawar, Peshawar 25120, Pakistan \\ 3 Department of Chemistry, University of Malakand, Chakdara 18800, Pakistan; sufaidkhan1984@uom.edu.pk \\ 4 Department of Physics, College of Khurma University College, Taif University, Taif 21944, Saudi Arabia; \\ k.hussein@tu.edu.sa \\ * Correspondence: bushrachem@sbbwu.edu.pk (B.B.); rznkhattak@sbbwu.edu.pk (R.K.)
}

\section{check for}

updates

Citation: Begum, B.; Ijaz, S.;

Khattak, R.; Qazi, R.A.; Khan, M.S.;

Mahmoud, K.H. Preparation and

Characterization of a Novel

Activated Carbon@Polyindole

Composite for the Effective Removal

of Ionic Dye from Water. Polymers

2022, 14, 3. https://doi.org/

$10.3390 /$ polym 14010003

Academic Editors: Magdalena

Czemierska and Aleksandra Szcześ

Received: 14 November 2021

Accepted: 16 December 2021

Published: 21 December 2021

Publisher's Note: MDPI stays neutral with regard to jurisdictional claims in published maps and institutional affiliations.

Copyright: (C) 2021 by the authors. Licensee MDPI, Basel, Switzerland. This article is an open access article distributed under the terms and conditions of the Creative Commons Attribution (CC BY) license (https:// creativecommons.org/licenses/by/ $4.0 /)$

\begin{abstract}
The present study is aimed at the synthesis and exploring the efficiency of a novel activated carbon incorporated polyindole (AC@PIN) composite for adsorptive removal of Malachite Green (MG) dye from aqueous solution. An AC@PIN hybrid material was prepared by in situ chemical oxidative polymerization. The physico-chemical characteristics of the AC@PIN composite were assessed using Fourier-transform infrared spectrometer, X-ray diffraction, scanning electron microscopy, energy dispersive $\mathrm{X}$-ray spectroscopy, ultraviolet visible spectroscopy, and determination of point of zero charge $\left(\mathrm{pH}_{\mathrm{PZC}}\right)$. A series of adsorption studies was conducted to evaluate the influence of operational parameters such as $\mathrm{pH}$, contact time, initial dye concentration, AC@PIN dosage, and temperature on dye adsorption behavior of developed composite. A maximum dye removal percentage $(97.3 \%)$ was achieved at the $\mathrm{pH}=10$, AC@PIN dosage $=6.0 \mathrm{mg}$, initial dye concentration $150 \mathrm{mg} \mathrm{L}^{-1}$, and temperature $=20^{\circ} \mathrm{C}$. The kinetic studies demonstrated that the adsorption of MG on AC@PIN followed pseudo-second-order model $\left(R^{2} \geq 0.99\right)$. Meanwhile, Langmuir isotherm model was founded to be the best isotherm model to describe the adsorption process. Finally, the recyclability test revealed that the composite exhibits good recycle efficiency and is stable after 5 cycles. The obtained results suggest that AC@PIN composite could be a potential candidate for the removal of MG from wastewater.
\end{abstract}

Keywords: conducting polymer composites; polyindole; activated carbon; adsorption; Malachite Green; wastewater treatment

\section{Introduction}

Designing a novel and cost-efficient material for the purification of wastewater is one of the hottest topic of research across the world. The roots cause of water contamination is industrial effluents, agriculture, and nuclear waste [1,2]. Effluents from textile, cosmetic, paint, printing, leather, and plastic industry, primarily contain a complex range of colored chemical substances and heavy metals. However, dye is the major culprit in water pollution. It is estimated that about 40,000 tons dyes end up in wastewater streams, annually [1,3,4]. The presences of these non-biodegradable dyes in small amount can drastically cause carcinogenicity, toxicity, and inhibit photosynthesis of aquatic plants as there is reduced penetration of dissolved oxygen and light in water $[1,2,5]$. Therefore, the removal of dyes from wastewater through an economic way is highly desirable [1].

Literature reports numerous physico-chemical and biochemical techniques like ozonation, ion exchange, photocatalytic degradation, membrane separation, coagulation, adsorption, and electrochemical methods have been practiced for the elimination of noxious 
organic dyes from water streams [1-5]. Among these, adsorption is the most commonly applicable, simple, and economically viable method for the treatment of wastewater. Besides, it is a convenient, efficient, and eco-friendly method for the removal of colorants [2,3,5]. The operation cost of adsorption process is mainly dependent upon the adsorbent material [1]. Ample of reports are available in literature on employing adsorbents such as biochar, chitosan, zeolite, activated carbon (AC), rice husk, clay, orange peel, polymers, and pine bark for water purification [1,4-6]. However, flammability, weak hydrophilic nature, and difficulty in regeneration and processability are the major constraints in the wide applicability of the already reported adsorptive material $[3,5]$.

Conjugated polymers like polyaniline (PANI), polypyrrole (PPy), etc., and their composites with various organic and inorganic materials have gained substantial attention of research in many applications, particularly in wastewater purification [1,3-5]. The attractive features like structural porosity, improved mechanical stability, regenerability, selectivity, and good adsorption capacity make polymer-based adsorbents as potential candidates for water decontamination. In addition, they are inexpensive, easy to synthesize, biodegradable, and environmental benign in nature $[1,4,5]$. Various researchers reported the potential applicability of conjugated polymers and their composites for the adsorption of noxious dyes from waste water. For instance, Abdelghani et al. [1] prepared PANI@Almond shell bionanocomposite through in situ interfacial oxidation method and used for the adsorptive removal of Orang $G$ dye from aqueous solution. The material showed $190.98 \mathrm{mg} \mathrm{g}^{-1}$ as maximum adsorption capacity. Similarly, Sudhindra et al. [5] prepared PANI-multi-walled carbon nanotubes composite and reported its ability as an efficient and reusable adsorbent for Methyl Orange dye from water. Mudassir et al. [7] reported that PANI@AC could be a potential adsorbent for Methyl Orange removal. Sarojini and co-worker [8] evaluated the performance of PPy-marine biomass biocomposite for the elimination of Malachite Green from wastewater. Moreover, Saima and co-researchers [9] prepared different polymeric biocomposites based on PANI, PPy, starch, chitosan, and sugarcane bagasse and successfully employed as adsorbents for the Acid Black-234 under various condition. Though, these polymeric composites are environmentally friendly, inexpensive, and effective for the decontamination of water from dyes, still there is a need for the other novel, upgraded, and efficient adsorbent materials with enhanced adsorption capacity and processability in water treatment process.

Polyindole (PIN), a newly emerging conjugated polymer and its composites, have found significant importance in many fields such as sensors, supercapacitors, batteries, anticorrosion, etc. The major reasons for its applicability are its excellent mechanical stability, reasonably good electro-activity, optical properties, etc. [10,11]. In addition, PIN-based materials have been employed for adsorptive removal of heavy metals from wastewater. For example, PIN nanofibers were used for adsorption of copper (II) by Zhijiang et al. [12]. Similarly, Cai, Z. et al. [13,14] prepared surface-functionalized PIN nanofibers for effective removal of $\mathrm{Cr}(\mathrm{VI}), \mathrm{Pb}(\mathrm{II})$, and $\mathrm{Cd}(\mathrm{II})$ from aqueous solutions. Besides, polyacrylonitrile/PIN composite and zinc oxide/magnesium oxide/PIN have been used for $\mathrm{Cu}$ (II) and $\mathrm{Pb}$ (II), respectively $[15,16]$. However, literature reveals no study on the usage of PIN and its composites for the removal of dye from water. Thus, it is hoped to obtain new polymeric composite in this work by merging PIN with AC that could not only upgrade the physical and chemical features of the composite for many physico-chemical processes, especially, dye adsorption, but also process the sustainability at a low cost. Based on the abovementioned facts, the present study was carried out to successfully synthesize a novel AC integrated PIN (AC@PIN) hybrid material for the first time, as far as we know, and investigate its efficacy for the removal of ionic dye, Malachite Green (MG), from the aqueous system (Scheme 1). The AC@PIN composite was prepared by a simple and scalable one-pot in situ chemical polymerization method. The MG adsorption efficiency of the prepared AC@PIN composite in terms of different experimental conditions including $\mathrm{pH}$, temperature, initial dye concentration, AC@PIN dosage, and contact time was evaluated. In addition, isotherm 
and kinetic studies of the MG adsorption on AC@PIN were performed by applying various mathematical models to the experimental data.

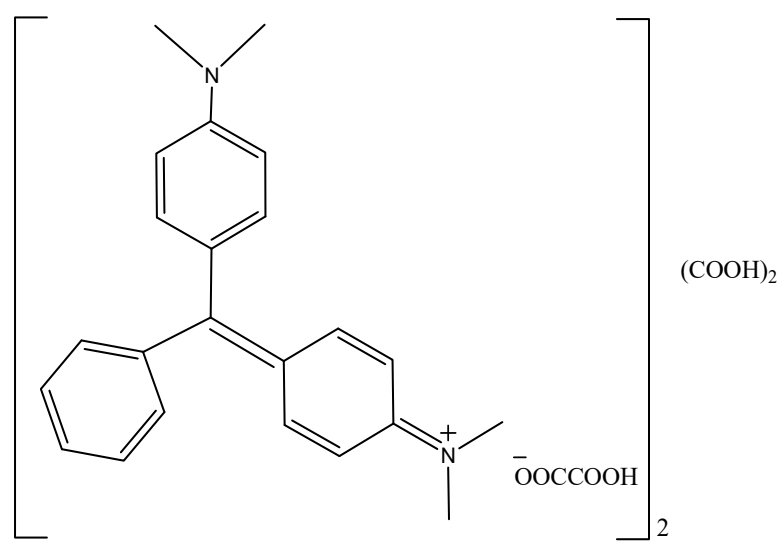

Scheme 1. Molecular structure of Malachite Green dye.

\section{Materials and Methods}

\subsection{Chemical and Reagents}

The indole $\left(\mathrm{C}_{8} \mathrm{H}_{7} \mathrm{~N},>99 \%\right)$, sodium dodecyl sulfate $\left(\mathrm{CH}_{3}\left(\mathrm{CH}_{2}\right)_{11} \mathrm{OSO}_{3} \mathrm{Na},>95 \%\right)$, benzoyl peroxide $\left(\mathrm{C}_{14} \mathrm{H}_{10} \mathrm{O}_{4},>98 \%\right)$, Malachite Green $\left(\mathrm{C}_{23} \mathrm{H}_{25} \mathrm{~N}_{2} \cdot \mathrm{C}_{2} \mathrm{HO}_{4} \cdot 0.5 \mathrm{C}_{2} \mathrm{H}_{2} \mathrm{O}_{4},>99 \%\right)$, sodium hydroxide $(\mathrm{NaOH},>99.8 \%)$, hydrochloric acid $(\mathrm{HCl}, 37 \%)$, and activated carbon (AC, 98\%) were purchased from Sigma Aldrich (St. Louis, MO, USA). Chloroform $\left(\mathrm{CHCl}_{3}\right.$, $>99 \%)$ and ethanol $\left(\mathrm{C}_{2} \mathrm{H}_{5} \mathrm{OH},>99 \%\right)$ were obtained from $\mathrm{BDH}$ (Poole, UK). Phosphoric acid $\left(\mathrm{H}_{3} \mathrm{PO}_{4}, 85 \%\right)$ and perchloric acid $\left(\mathrm{HClO}_{4},>70 \%\right)$ used in the experiment were borrowed from Scharlau (Barcelona, CAT, Spain). Malachite Green stock solution $\left(1 \mathrm{~g} \mathrm{~L}^{-1}\right)$ was prepared by dissolving an accurately weighed amount of dye in deionized water, and the desired working concentrations were prepared using the stock solution. All these research grade chemicals were used as received without any further processing.

\subsection{Chemical Activation of $A C$}

Commercially available AC was chemically activated using $30 \% w / v \mathrm{H}_{3} \mathrm{PO}_{4}$ solution. In context to this, $\mathrm{AC}$ was mixed with $\mathrm{H}_{3} \mathrm{PO}_{4}$ solution to make slurry of 1:1. The mixture was stirred for about $2-3 \mathrm{~h}$ to make it uniform. The slurry was dried in an oven at $120^{\circ} \mathrm{C}$ for $6 \mathrm{~h}$ and then cooled to room temperature. Subsequently, the mixture was washed thoroughly with double distilled water to remove extra phosphate ions and then dried again in an oven at $100{ }^{\circ} \mathrm{C}$ for $24 \mathrm{~h}$ to remove moisture.

\subsection{Synthesis of AC@PIN Composite}

AC@PIN composite was synthesized via in situ chemical oxidative polymerization using varying amount of AC. The process of synthesis was executed by gradual addition of $0.644 \mathrm{~g}$ of benzoyl peroxide into $250 \mathrm{~mL}$ beaker loaded with $30 \mathrm{~mL}$ of chloroform while being on constant mechanical stirring. Subsequently, $0.020 \mathrm{~g}$ of sodium dodecylsulfate followed by AC $(0.01-0.3 \mathrm{~g})$ dispersed in $1 \mathrm{M} \mathrm{HClO}_{4}(30 \mathrm{~mL})$ was slowly added to above oxidizing mixture. Afterwards, $0.249 \mathrm{~g}$ of indole was introduced into reaction flask. Constant mechanical stirring for about $24 \mathrm{~h}$ at room temperature yielded a greenish colored product. Around $5-10 \mathrm{~mL}$ of ethanol was poured to stop the reaction. The polymer precipitates were then filtered and washed with ethanol until a light yellowish filtrate was obtained and it was then dried. The possible polymerization mechanism is presented in Scheme 2. 


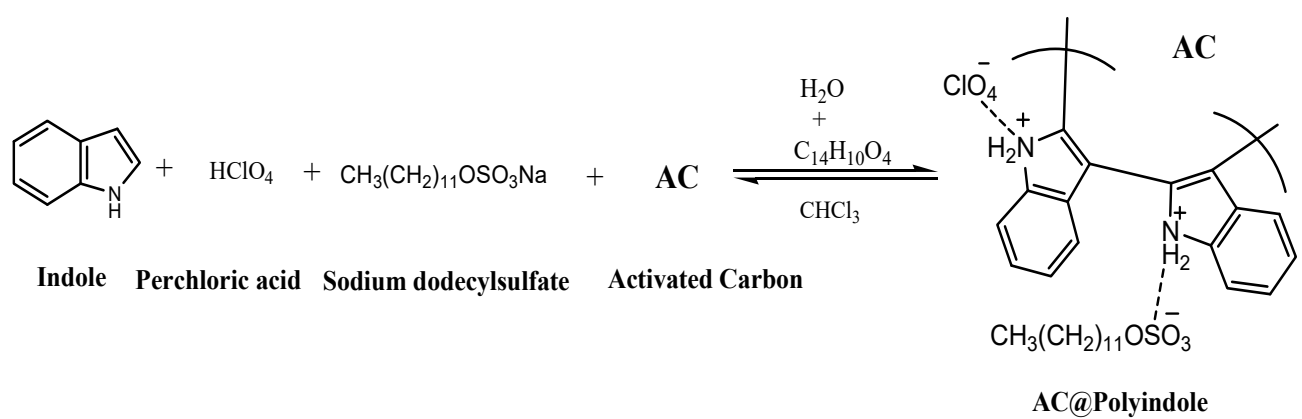

Scheme 2. Probable polymerization mechanism of AC@PIN.

A series of experiments were carried out with varying amount of $\mathrm{AC}$, i.e., $0.01 \mathrm{~g}$ (AC@PIN-1), $0.10 \mathrm{~g}$ (AC@PIN-2), $0.25 \mathrm{~g}$ (AC@PIN-3), and $0.30 \mathrm{~g}$ (AC@PIN-4) via keeping concentration of all other components constant.

For comparison, pristine polymer (PIN) without AC was also synthesized using same chemical polymerization method.

\subsection{Characterizations}

The functional group analysis and molecular structures of PIN based polymers were evaluated by Fourier Transform Infra-Red (FTIR) spectrometer (Schimadzu IR Prestige-21, Duisburg, Germany), in the range of $400-4000 \mathrm{~cm}^{-1}$. The polymer crystallinity was investigated by using X-ray diffractometer (XRD) (Malvern Panalytical, Malvern, UK) technique equipped with $(\mathrm{Cu}-\mathrm{K} \alpha)$ radiations source in 2theta range of $10-80^{\circ}$. Scanning Electron Microscopy (SEM) (TESCAN Vega 3, Brno, Czechia) was used for morphological studies, whereas Energy Dispersive X-ray (EDX) (Vario EL CHNS, ElementarAnalysensysteme $\mathrm{GmbH}$, Hanau, Germany) spectroscopic analysis was carried out to examine the elemental composition of prepared polymer composites. The optical absorption properties were studied by using UV-Vis spectrophotometer (UV-1800, Schimadzu, Kyoto, Japan) and spectra obtained are recorded in the range of $200-800 \mathrm{~nm}$ in ethanol.

The point of zero charge $\left(\mathrm{pH}_{\mathrm{PZC}}\right)$ of AC@PIN composite was obtained by the solid addition method using $0.1 \mathrm{M} \mathrm{NaCl}$ solution [17]. Assays were performed in a series of glass vials, each containing $20 \mathrm{~mL}$ of $0.1 \mathrm{M} \mathrm{NaCl}$ solution. The initial $\mathrm{pH}\left(\mathrm{pH}_{\mathrm{i}}\right)$ was adjusted using either $0.1 \mathrm{M} \mathrm{NaOH}$ or $0.1 \mathrm{M} \mathrm{HCl}$ solution. Then, $0.002 \mathrm{~g}$ of AC@PIN was added to each vial and the suspension was stirred at $20{ }^{\circ} \mathrm{C}$ temperature for $24 \mathrm{~h}$ with continuous shaking (@300 RPM). The final $\mathrm{pH}\left(\mathrm{pH}_{\mathrm{f}}\right)$ of each suspension was recorded and $\mathrm{pH} \mathrm{PZC}_{\mathrm{C}}$ was obtained from the graph between $\Delta \mathrm{pH}$ verses $\mathrm{pH}_{\mathrm{i}}$.

\subsection{Adsorption Studies}

Initially, we tested PIN, AC, and AC@PIN composite for the removal of MG. For each prepared adsorbent, the adsorption study was performed using a known amount of adsorbent in contact with $20 \mathrm{~mL}$ of the MG solution at neutral $\mathrm{pH}$ and at room temperature.

The adsorption behavior of MG onto the AC@PIN composite was analyzed via Batch mode studies under various experimental conditions such as solution $\mathrm{pH}$ (from 2 to 10), AC@PIN dosage (from 6.0 to $8.0 \mathrm{mg}$ ), adsorption contact time (from 0 to $60 \mathrm{~min}$ ), MG initial concentration (from 50 to $200 \mathrm{mg} \mathrm{L}^{-1}$ ), and temperature (from 20 to $55{ }^{\circ} \mathrm{C}$ ). The influence of the operational parameters on the adsorption efficiency of AC@PIN was evaluated by varying one variable at a time. The $\mathrm{pH}$ was adjusted by adding an appropriate volume of $\mathrm{NaOH}(0.1 \mathrm{M})$ or $\mathrm{HCl}(0.1 \mathrm{M})$ solutions. The concentration of MG before and after adsorption was determined from the calibration curve of a series of working concentrations of MG according to Beer-Lambert's law at the pre-determined $\lambda_{\max }$ $(614 \mathrm{~nm})$. The absorbance values (at $614 \mathrm{~nm}$ ) of each solution were measured from UV-Vis spectra recorded by a UV-Vis spectrophotometer (Schimadzu, UV-1800). Afterwards, the MG adsorption onto AC@PIN composite was confirmed by separating the adsorbent from 
the MG solution after adsorption. The dye adsorbed capacity $\left(\mathrm{Q}_{\mathrm{t}}, \mathrm{mg} \mathrm{g}^{-1}\right)$ and percent removal efficiency $(R, \%)$ were calculated using Equations (1) and (2), respectively $[5,6]$.

$$
\begin{gathered}
\mathrm{Qt}=\left[\left(\mathrm{C}_{\mathrm{o}}-\mathrm{C}_{\mathrm{t}}\right) / \mathrm{m}\right] \times \mathrm{V} \\
\mathrm{R}=\left[\left(\mathrm{C}_{\mathrm{o}}-\mathrm{C}_{\mathrm{t}}\right) / \mathrm{C}_{\mathrm{o}}\right] \times 100
\end{gathered}
$$

where $\mathrm{C}_{\mathrm{o}}\left(\mathrm{mg} \mathrm{L}^{-1}\right)$ is initial dye concentration, $\mathrm{C}_{\mathrm{t}}\left(\mathrm{mg} \mathrm{L}^{-1}\right)$ is the dye concentration at any time, $\mathrm{V}(\mathrm{L})$ is the volume of solution, and $\mathrm{m}(\mathrm{g})$ is the mass of the adsorbent.

The adsorbent reusability was investigated by the adsorption and desorption of MG loaded AC@PIN composite. The regenerated AC@PIN was filtered, washed repeatedly with deionized water, dried, and then reactivated using $1 \mathrm{M} \mathrm{HClO}_{4}$ for $2 \mathrm{~h}$ at $20^{\circ} \mathrm{C}$ under constant stirring. The desorbed AC@PIN was again used for the MG adsorption under optimized operating conditions. This process was repeated for five cycles.

\section{Results and Discussion}

\subsection{Chemical Structure Analysis}

The FTIR spectra of pristine PIN, AC, and AC@PIN composites synthesized via chemical route are presented in Figure 1a,b.The FTIR spectrum of PIN displays sharp bands located at $717 \mathrm{~cm}^{-1}, 1417 \mathrm{~cm}^{-1}$ and $1513 \mathrm{~cm}^{-1}$ indicates out of plane deformation of $\mathrm{C}-\mathrm{H}$ bond in benzene ring, stretching mode of $\mathrm{C}-\mathrm{N}$, and indole, respectively $[18,19]$. The incorporation of $\mathrm{ClO}_{4}{ }^{-}$from $\mathrm{HClO}_{4}$ in $\mathrm{PIN}$ is indicated by $\mathrm{Cl}-\mathrm{O}$ stretching peak at $1036 \mathrm{~cm}^{-1}$ [20]. The bands located at $1589 \mathrm{~cm}^{-1}$ and $1187 \mathrm{~cm}^{-1}$ were assigned to $\mathrm{C}=\mathrm{C}$ vibration mode of aromatic ring and asymmetric stretching of $\mathrm{S}=\mathrm{O}$ that originates from $\mathrm{SO}^{3-}$ anion of SDS, respectively [21,22]. The doping of SDS and $\mathrm{HClO}_{4}$ in PIN was verified by the presence of $\mathrm{S}=\mathrm{O}$ and $\mathrm{ClO}_{4}{ }^{-}$bands in FTIR spectrum [20]. Moreover, the stretching vibration of $\mathrm{N}-\mathrm{H}$ bond in pyrrole ring is located as a wide band at $3112 \mathrm{~cm}^{-1}$ whereas, the presence of $\mathrm{N}-\mathrm{H}$ bond suggested that nitrogen is not involved in polymerization mechanism and thus the possible polymerization sites are located at $\mathrm{C}-2$ and $\mathrm{C}-3$ points of pyrrole ring in the indole [19].

In the FTIR spectrum of AC, the peaks positioned at $3741 \mathrm{~cm}^{-1}$ and $1649 \mathrm{~cm}^{-1}$ are allocated to $-\mathrm{OH}$ of water molecules and stretching vibrations for $\mathrm{C}=\mathrm{O}$ in carboxylic, aldehyde and ketones group, respectively. The peak at $1514 \mathrm{~cm}^{-1}$ is ascribed to $\mathrm{C}=\mathrm{C}$ in aromatic ring stretching $[23,24]$. There is a broad band at $1294 \mathrm{~cm}^{-1}$ that is attributed to stretching vibration observed for $\mathrm{C}-\mathrm{O}$ bond due to presence of acid, phenol, ether, esters and alcohol. Furthermore, band at $1128 \mathrm{~cm}^{-1}$ notifies the presence of groups containing phosphorous and oxygen species like symmetric vibration in $\mathrm{P}-\mathrm{O}-\mathrm{P}$ linkage and ionized linkage $\mathrm{P}^{+}-\mathrm{O}^{-}$ in acid phosphate ester [25]. The indication of groups composed of phosphorus species are attributed by presence of band around $1183 \mathrm{~cm}^{-1}$ due to vibration in $\mathrm{H}$-bonded $\mathrm{P}=\mathrm{O}$, $\mathrm{P}-\mathrm{O}-\mathrm{C}$ stretching of $\mathrm{O}-\mathrm{C}$ bond in aromatic linkage and to $\mathrm{P}=\mathrm{OOH}[23,25]$.

All the characteristic peaks of PIN and AC were observed in the spectra of PIN@AC with the little effect in peak intensities and positions corresponding to varying amount of $\mathrm{AC}$ added. The pointed peak centered at $717 \mathrm{~cm}^{-1}$ representing out of plane deformation of $\mathrm{C}-\mathrm{H}$ bond shows shift towards higher wavenumber, i.e., $727 \mathrm{~cm}^{-1}$. The $\mathrm{Cl}-\mathrm{O}$ stretching band at $1036 \mathrm{~cm}^{-1}$ shows a shift to a lower wavenumber with the little increase in the broadness, but further increase in AC amount makes it to shift to $1039 \mathrm{~cm}^{-1}$. Similarly, the peak pointed at $1187 \mathrm{~cm}^{-1}$ for antisymmetric stretching of the $\mathrm{S}=\mathrm{O}$ slightly slides towards lower wavenumber. The peak positioned at $1514 \mathrm{~cm}^{-1}$ is less visible, which becomes broad and more visible in composite samples with the shift towards higher wavenumber $1549 \mathrm{~cm}^{-1}$ showing the presence of aromatic ring. Upon further increase in AC amount, the peaks shifted downfield $\left(1547 \mathrm{~cm}^{-1}\right)$. The peak shifting to lower wavenumber region may be due to various stretching vibration of benzene ring that resulted from the interaction of $\mathrm{AC}$ and $\pi-\pi$ conjugation of polymer chain $[26,27]$. Besides, the phosphorous containing groups' ( $\mathrm{P}-\mathrm{O}-\mathrm{P}, \mathrm{P}^{+}-\mathrm{O}^{-}, \mathrm{P}=\mathrm{O}, \mathrm{P}-\mathrm{O}-\mathrm{C}, \mathrm{P}=\mathrm{OOH}$ ) vibrations were also observed at $1128 \mathrm{~cm}^{-1}$ and $1187 \mathrm{~cm}^{-1}$, showing the incorporation of AC into PIN main chain. Furthermore, no 
extra peak was observed in composite samples except for characteristic peaks of polymer salt and AC [28,29]. The relative shift in peaks positions and presence of peaks for AC in composited samples confirms the formation of AC@PIN composite [29,30].

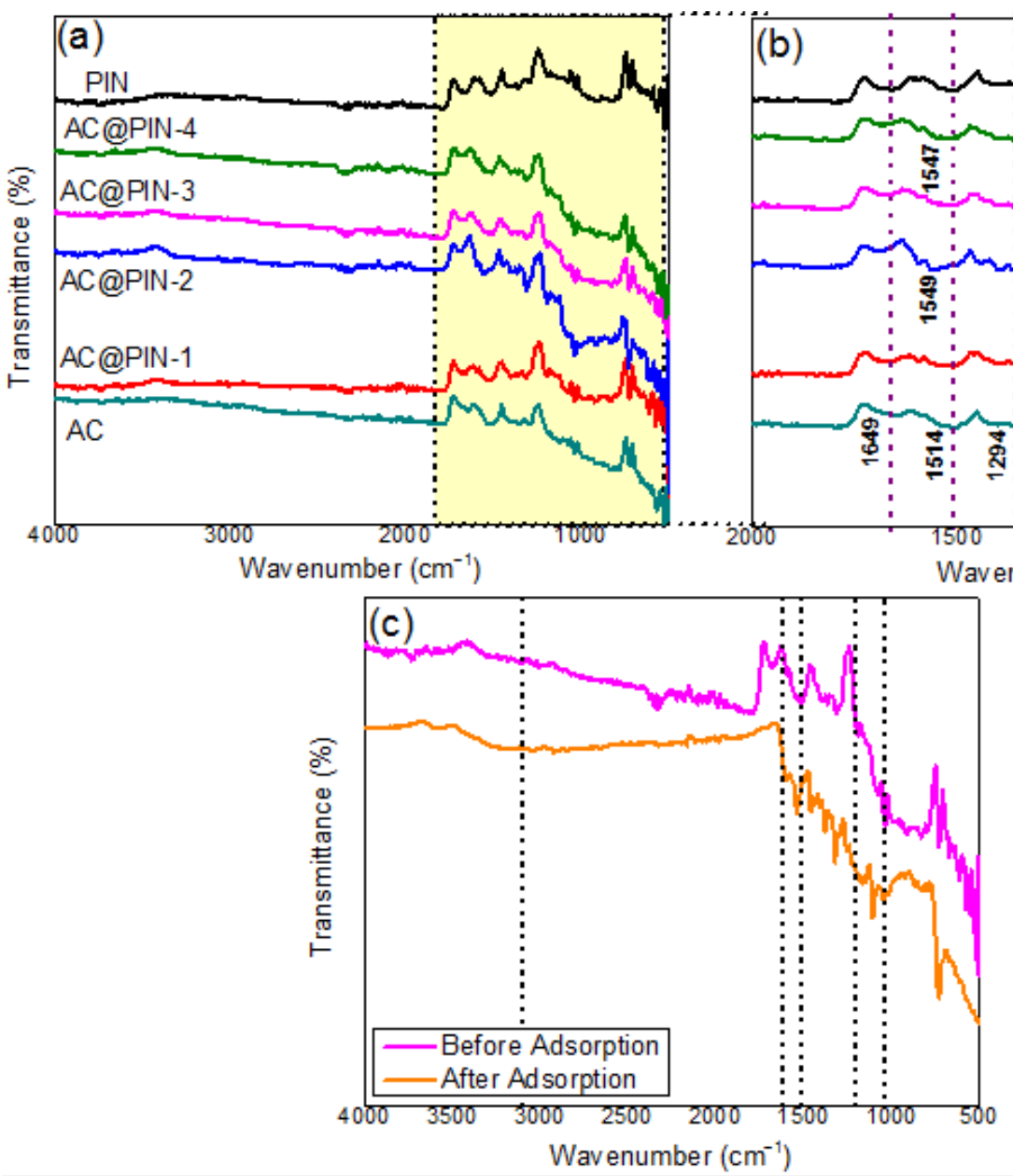

Figure 1. FTIR spectra of (a) PIN, AC, and AC loaded various AC@PIN composites, (b) re-scaled spectra from 2000 to $500 \mathrm{~cm}^{-1}$, and (c) comparative spectra of AC@PIN-3 before and after adsorption of MG dye.

In addition, FTIR spectrum of AC@PIN after adsorption was also measured in order to confirm the adherence of dye with the surface (Figure 1c). Some changes in the vibrational frequencies of characteristic peaks were observed in the range of $1000-3300 \mathrm{~cm}^{-1}$ after MG adsorption. The peaks located at the 1036, 1187, 1513, and $1586 \mathrm{~cm}^{-1}$ shifted to 1039 , 1189,1538 , and $1600 \mathrm{~cm}^{-1}$, respectively. These results indicate the interaction of MG with the functional groups at the surface of AC@PIN composite. Similar results were already reported in the literature [31,32].

\subsection{Surface Morphology Analysis}

SEM in conjugation with EDX spectroscopy was implemented for surface topographi$\mathrm{cal}$, chemical composition characterization and to acquire information regarding elements present in sample as well as their percentage amounts, respectively.

Figure 2a depicts the SEM micrographs of PIN. It is evident that PIN has the agglomerated interlaced nano-fibrous structure and the diameter of nano-fibers measured is $33.87 \mathrm{~nm}$ and $35.34 \mathrm{~nm}$. The agglomeration of fibers can be attributed to the presence of SDS surfactant in polymer that encompasses negative head group (being anionic surfactant) adheres well with positively charge PIN $[22,33]$. Figure $2 b$ represents the SEM image of 
$\mathrm{H}_{3} \mathrm{PO}_{4}$ impregnated $\mathrm{AC}$, which shows the uneven and ruptured morphology with pores or cavities on the irregular surface of $\mathrm{AC}$. The removal of activating agent $\left(\mathrm{H}_{3} \mathrm{PO}_{4}\right)$ during activation is the cause of formation of cavities [23]. The surface morphologies of PIN@AC composites are shown in Figure 2c-f. It can be seen that as the amount of AC is increased in composite sample, the nanofibers merged with each other and the interaction between AC and polymer was observed. The surface texture changes and fibers become less visible. Henceforth, the nanostructures with empty voids might be expected to exhibit good adsorptive properties facilitating easy penetration of dye molecules.Thus, it was revealed that using highest amount of AC in composite sample resulted in surface roughness and reduced porosity with disappearance of nanofibers due to dominating effect of AC over polymer fibers morphology [34,35].

Moreover, SEM micrograph of AC@PIN-3 after MG adsorption is illustrated in Figure 2g. The image shows a smooth, even, and non-porous surface after adsorption clearly indicates the interaction of composite with dye.
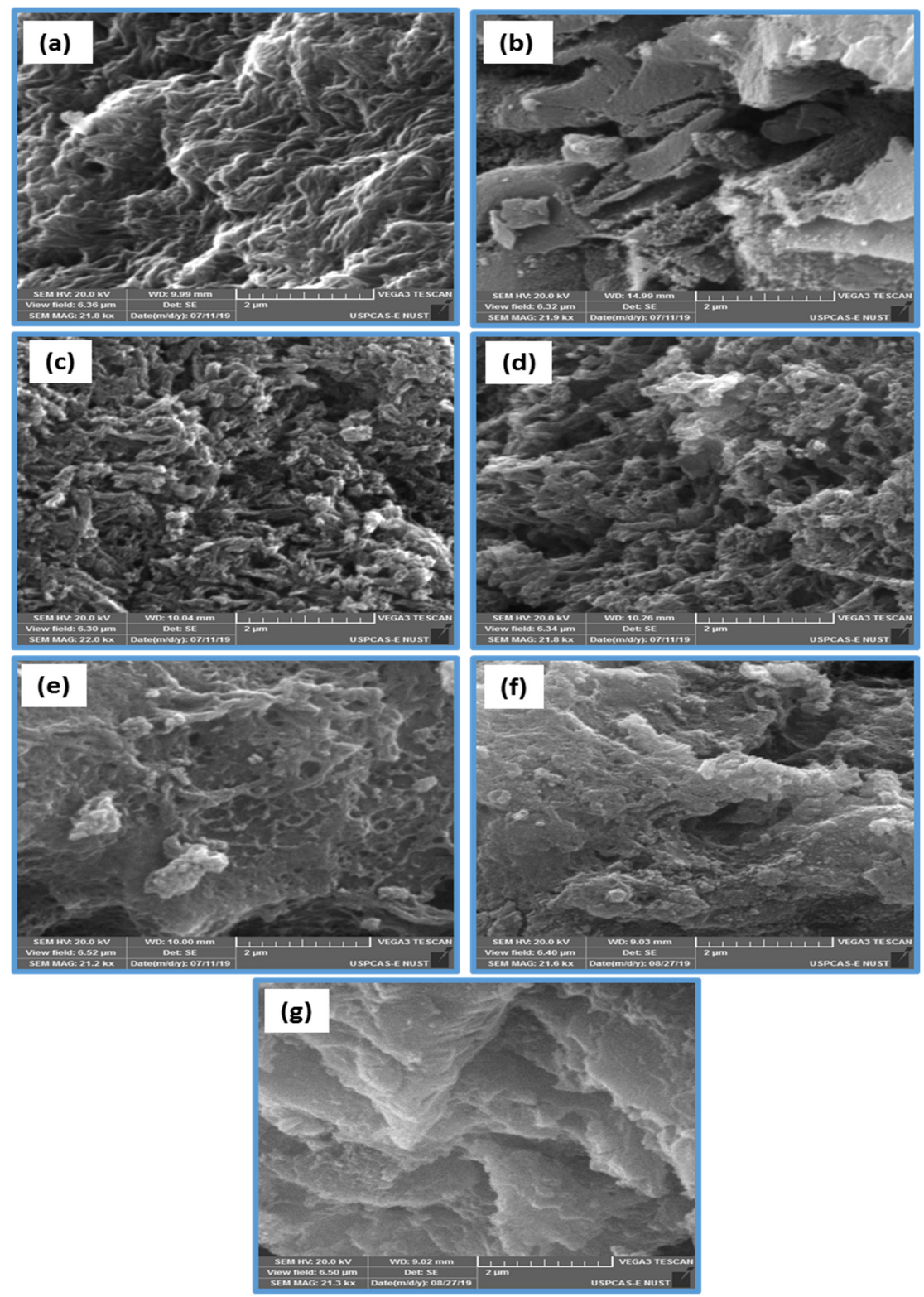

Figure 2. SEM micrographs of (a) PIN, (b) AC, and (c) AC@PIN-1, (d) AC@PIN-2, (e) AC@PIN-3, (f) AC@PIN-4 composite before adsorption, and (g) AC@PIN-3 after adsorption at the magnification of $2.0 \mu \mathrm{m}$. 


\subsection{EDX Analysis}

The elemental composition in EDX report of pristine and AC is shown in Figure 3. The presence of $\mathrm{C}, \mathrm{N}, \mathrm{O}, \mathrm{S}$, and $\mathrm{Cl}$ revealed the successful synthesis of PIN doped with acid as well as surfactant.

The sulfur $(0.73 \mathrm{wt} . \%)$ and $\mathrm{Cl}(2.70 \mathrm{wt} . \%)$ content presented the incorporation of SDS and $\mathrm{HClO}_{4}$, respectively. Moreover, the presence of $\mathrm{P}(2.06 \mathrm{wt} . \%)$ in EDX spectrum of AC confirms the chemical activation with $\mathrm{H}_{3} \mathrm{PO}_{4}$. However, the trace amounts of $\mathrm{Ca}$ and $\mathrm{Na}$ in EDX spectrum of AC shows might be referred to be coming from the precursor used for AC preparation. Furthermore, we obtained the elemental compositions of AC@PIN composite (Figure 3c). The data of elemental analysis showed all the characteristic elements observed in EDX spectra of PIN and AC. The carbon content is increased to 77.31 (wt.\%) in AC@PIN-3, which confirms the integration of AC with PIN matrix.
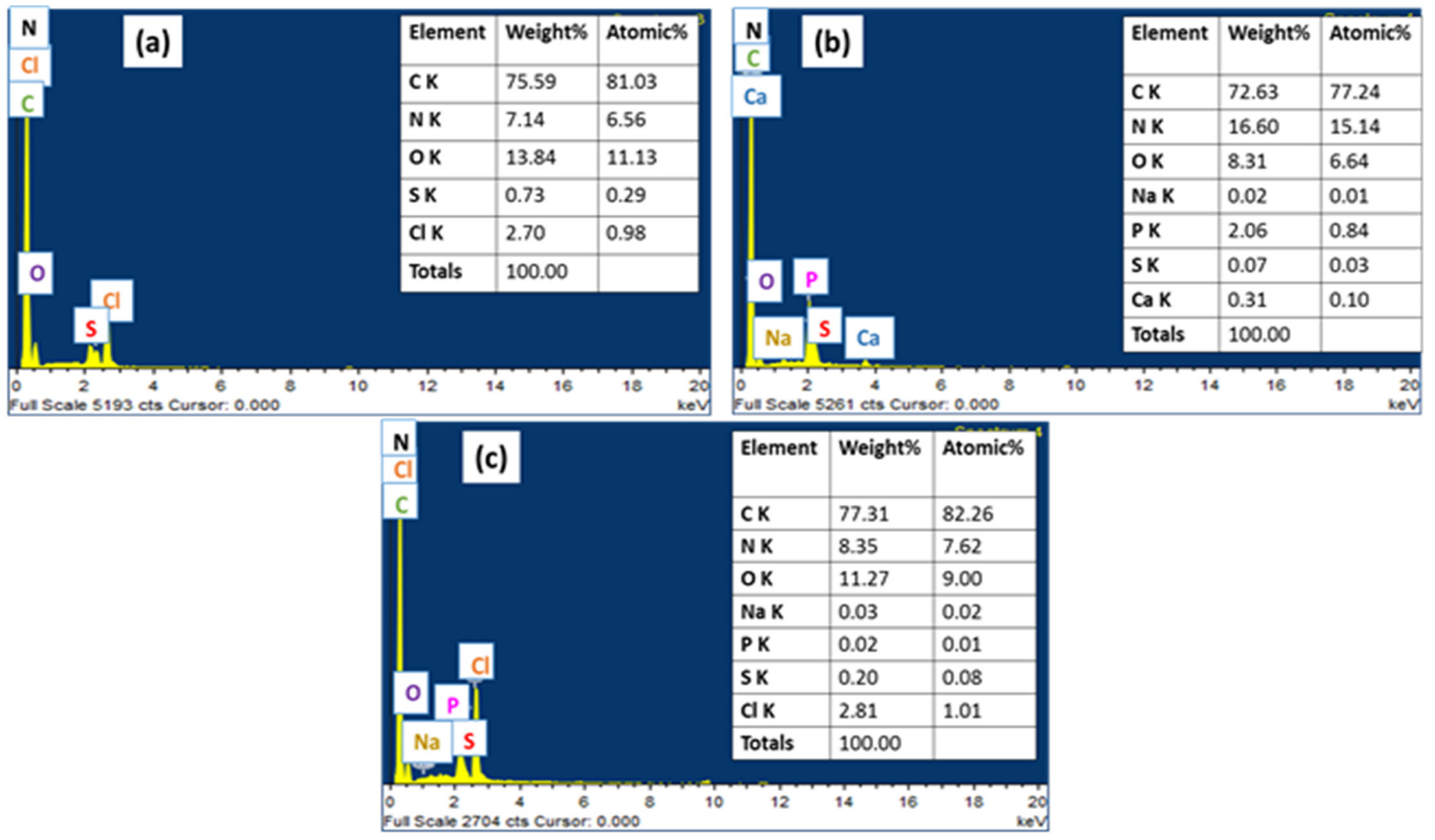

Figure 3. EDX spectra of (a) PIN, (b) AC, and (c) AC@PIN-3 composite.

\subsection{X-ray Diffraction Analysis}

XRD analysis of AC shown in Figure 4 depicts two characteristic diffraction peaks for $\mathrm{AC}$ centered at $2 \theta$ values of $22.8^{\circ}$ and $39.04^{\circ}$. The XRD plot revealed amorphous nature of $\mathrm{AC}$ with the very little percentage of crystallinity that is consistent with previous researches. The ordered crystalline phase is negligible, which leads to amorphous nature of AC [36]. The presence of third pointed peak in the sample may arise due to leftover or excess ash in carbon sample [37].

The XRD spectrum of PIN exhibited peaks at $20.06^{\circ}$ and $34.44^{\circ}$ (Figure 4 ). The broad peak confirms the indole polymerization. These peaks confirmed amorphous nature of the synthesized polymer [38,39]. The XRD pattern recorded for the AC@PIN composites showed similar characteristic increase in 2theta values for AC@PIN composites. Hence, the shift in peaks positions to right and increase in peak broadness is attributed to the presence of AC which confirms the formation of AC@PIN composite [40]. Thus, characteristic peaks of polymer are less visible which on addition of $\mathrm{AC}$ in composite resulted in domination of peaks for AC with increase intensity. 


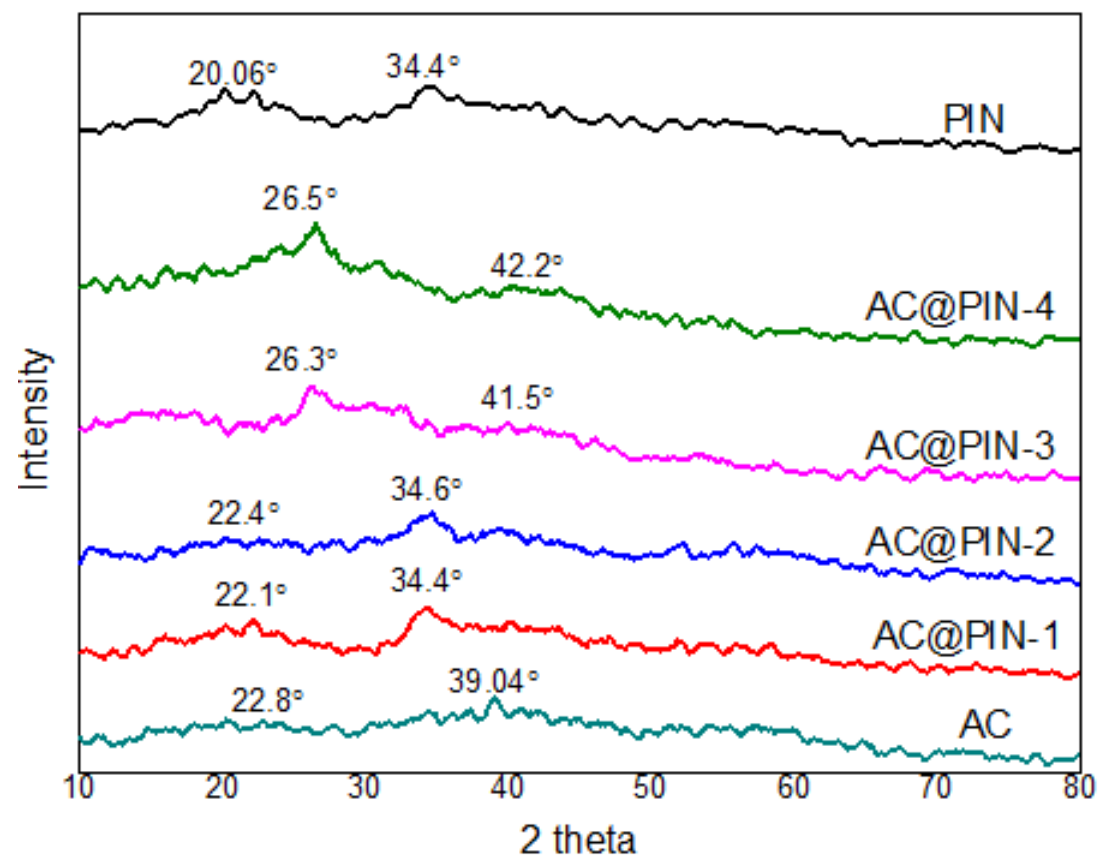

Figure 4. Comparison of XRD pattern of PIN and PIN@AC composites.

\subsection{UV-Visible Spectroscopy}

UV-Vis linear absorption spectra for PIN, AC, and AC@PIN composites that were dissolved in ethanol are shown in Figure 5. For PIN, numerous peaks appeared. Peaks at $254 \mathrm{~nm}$ originates from $\mathrm{n}-\pi^{*}$ transition, whereas peaks positioned at $325 \mathrm{~nm}$ and $388 \mathrm{~nm}$ are due to the $\pi-\pi^{*}$ transition. Moreover, absorption peak at $428 \mathrm{~nm}$ and $505 \mathrm{~nm}$ arises due to polaronic transition in PIN [41,42]. Compared to indole UV-Vis spectrum as in the literature, the presence of more peaks with their shift towards the longer wavelength (bathochromic shift) in the spectra of PIN provides the evidence of higher extent of $\pi$ electronic conjugation in polymer. The enhanced $\pi$-electronic conjugation results in more $\pi$ bonds and thus improvement in delocalization of electron along pi-bond of PIN synthesized is recorded $[43,44]$. On the other hand, UV-Vis spectrum of AC shows a sharp and a broad band below $35 \mathrm{~nm}$, which represents $n-\pi^{*}$ and $\pi-\pi^{*}$ transitions, respectively.

Figure 5 shows UV-Vis spectra of AC@PIN composites. From the spectra, it is evident that with increasing $\mathrm{AC}$ amount, a change in band intensity was observed compared to PIN doped with only $\mathrm{HClO}_{4}$ and surfactant SDS. With increasing $\mathrm{AC}$ content, the intensities for the peaks associated with $\pi-\pi^{*}$ transition was decreased and shifted to longer wavelength. Absorbance at $325 \mathrm{~nm}$ shifted to $343 \mathrm{~nm}$ and the peak positioned at $389 \mathrm{~nm}$ for polymer sample shifted to $397 \mathrm{~nm}$ with rising AC amount up to $0.25 \mathrm{~g}$. However, on further addition of AC beyond $0.24957 \mathrm{~g}$ cause a reduction $(391 \mathrm{~nm})$ in wavelength. Moreover, third peak was found to experience little shift from $424 \mathrm{~nm}$ to $428 \mathrm{~nm}$ with addition of AC. The decrease in intensity of peak was observed, which may be attributed to decrease in conjugation of PIN due to composite formation with AC $[35,45]$. 


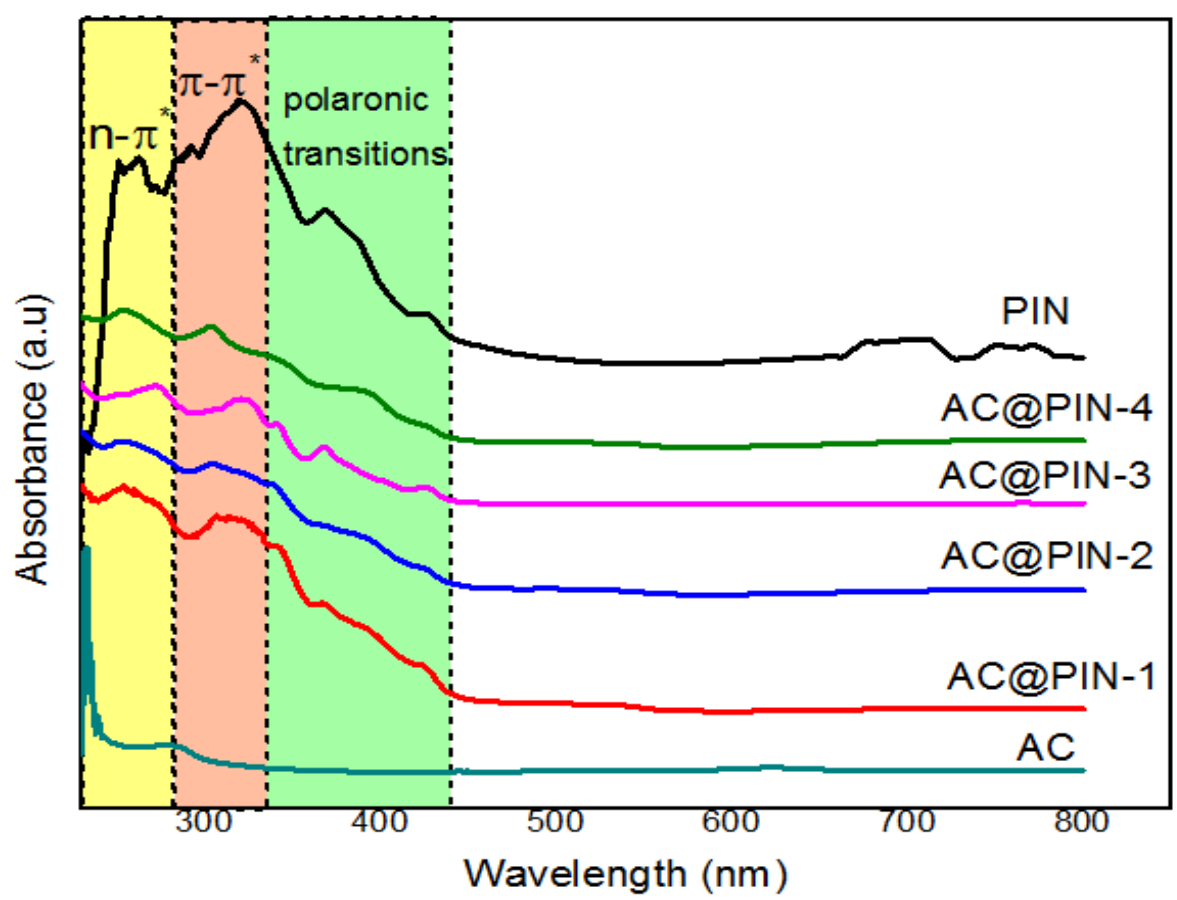

Figure 5. UV-Vis spectra of PIN, AC, and AC@PIN composites.

\subsection{Point of Zero Charge $\left(\mathrm{pH}_{\mathrm{PZC}}\right)$}

The adsorption capacity of AC@PIN composite and the nature of binding sites were determined from the point of zero charge $\left(\mathrm{pH}_{\mathrm{PZC}}\right)$. When the $\mathrm{pH}$ is less than $\mathrm{pH}_{\mathrm{PZC}}$, the surface of adsorbent is expected to be negatively charged and it allows adsorption of positive ions. At $\mathrm{pH}$ greater than $\mathrm{pH}_{\mathrm{PZC}}$, the adsorption of anions is more favorable due to increased positive ions at the adsorbent surface [8]. As shown in Figure 6, the $\mathrm{pH}_{\mathrm{PZC}}$ for AC@PIN composite is 8.0. Thus, it can be inferred that protonation of surface functional groups of AC@PIN occurred below $\mathrm{pH}_{\mathrm{PZC}}$ and a strong electrostatic forces of attraction was developed between the anions of MG with the surface positive charges. Conversely, the negatively charged groups dominated the AC@PIN surface at $\mathrm{pH}$ greater than $\mathrm{pH}$ PZC. Therefore, adsorption of cationic dye, $\mathrm{MG}$, was favored above $\mathrm{pH}=8.0$.

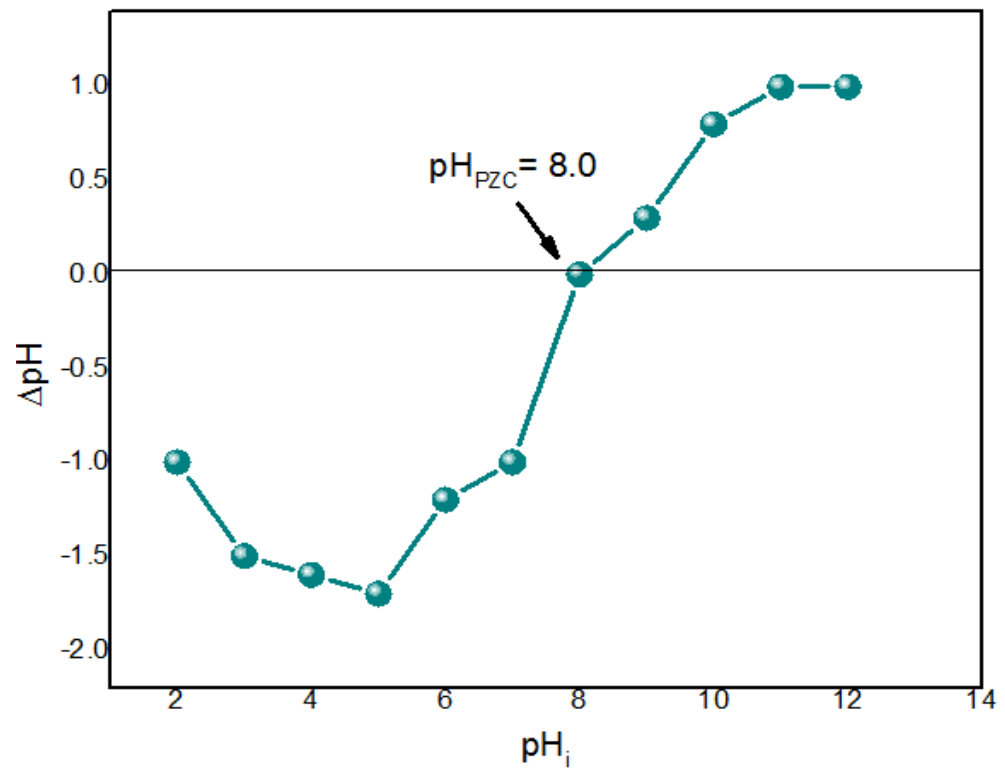

Figure 6. Point of zero charge ( $\left.\mathrm{pH}_{\mathrm{PZC}}\right)$ of AC@PIN composites. 


\subsection{Adsorption Studies}

\subsubsection{Adsorption Efficiency of Prepared PIN, AC, and AC@PIN}

Figure $7 \mathrm{a}$ shows the adsorption efficiency of the three prepared adsorbent materials for the removal of MG from aqueous solution. It is clear from the graph that the adsorption efficiency of AC, PIN, and AC@PIN composite was 60.9\%,68.0\%, and $94.9 \%$, respectively. The maximum MG uptake of $101.5,113.3$, and $158.2 \mathrm{mg} \mathrm{g}^{-1}$ was attained by AC, PIN, and AC@PIN composite, respectively. These results revealed that the adsorption properties of the prepared AC@PIN composite have been greatly enhanced due to the integration of the two components (AC and PIN). Therefore, we selected AC@PIN composite as better adsorbent material for MG removal. The detailed investigation of adsorptive behavior of AC@PIN was carried out and the results are discussed below.

\subsubsection{Influence of $\mathrm{pH}$ and Contact Time}

To understand the adsorption process, the study of various factors effecting the adsorbent/solution interface needs to be evaluated. One of the major factor that influences the adsorption phenomenon is solution $\mathrm{pH}$ as it affects the adsorbent surface charge, ionization state, and solubility of dye [17,32]. Therefore, we carried out the adsorption of MG on the AC@PIN composite as a function of $\mathrm{pH}$ ranging from 2 to 10 at $20{ }^{\circ} \mathrm{C}$. The dye initial concentration was $50 \mathrm{mg} \mathrm{L}^{-1}$. The effects of $\mathrm{pH}$ on the adsorptive removal of $\mathrm{MG}$ by AC@PIN composite are presented in Figure $7 \mathrm{~b}, \mathrm{c}$. It can be seen from the figure that the percent removal of $\mathrm{MG}$ was $16.4 \%$ and $42 \%$ at $\mathrm{pH}=2$ and 6 , respectively. This can be attributed to the positively charged surface of the AC@PIN composite at $\mathrm{pH}<\mathrm{pH} \mathrm{PZC}_{\text {, }}$ which is less favorable for interaction with cations of MG. It is expected that the surface might adsorb $\mathrm{H}^{+}$ions from aqueous system, becomes positively charged, and cause electrostatic repulsion between the AC@PIN surface and MG cations. Hence, it results in the less adsorption of $\mathrm{MG}$ from solution in acidic $\mathrm{pH}[2,46]$. On the other hand, a marked increase in the percent removal of MG adsorption was observed as the $\mathrm{pH}$ is increased from 6 to 10 . Interestingly, around $92 \%$ of $\mathrm{MG}$ was adsorbed from the solution which is ascribed to the deprotonation of the AC@PIN composite surface resulting in the more negative charges at $\mathrm{pH}>\mathrm{pH}_{\mathrm{PZC}}$. Therefore, the electrostatic attraction between the composite and MG cations increases, which facilitates the removal of MG. Based on these results, it can be concluded that the alkaline $\mathrm{pH}$ favored MG adsorption, therefore, further adsorption experiments were performed at $\mathrm{pH}=10[31,46]$.

The dye contact time with AC@PIN composite determines the optimum time required for adsorption process to attain equilibrium [17]. The adsorption of MG from aqueous solution at different time intervals (0-60 $\mathrm{min})$ and at various $\mathrm{pH}(2-10)$ was investigated and the results are displayed in Figure $7 \mathrm{~b}$. In the initial 10-15 min of contact with the AC@PIN composite, the adsorption of MG is fast, and then, it decreases as equilibrium point is reached in around $40 \mathrm{~min}$ at each $\mathrm{pH}$. This is ascribed to the fact that a large number of adsorption active sites are accessible to MG in the start of contact. With the passage of time, the dye cations accumulated at the surface of AC@PIN composite, which restricts the other ions to penetrate deep into the adsorbent molecular structure. Hence, the adsorption rate is reduced and equilibrium situation is achieved. These results are consistent with the previous reports $[4,17,32]$. Based on these results, 60 min contact time was considered as the optimum equilibrium time throughout the experiments. 

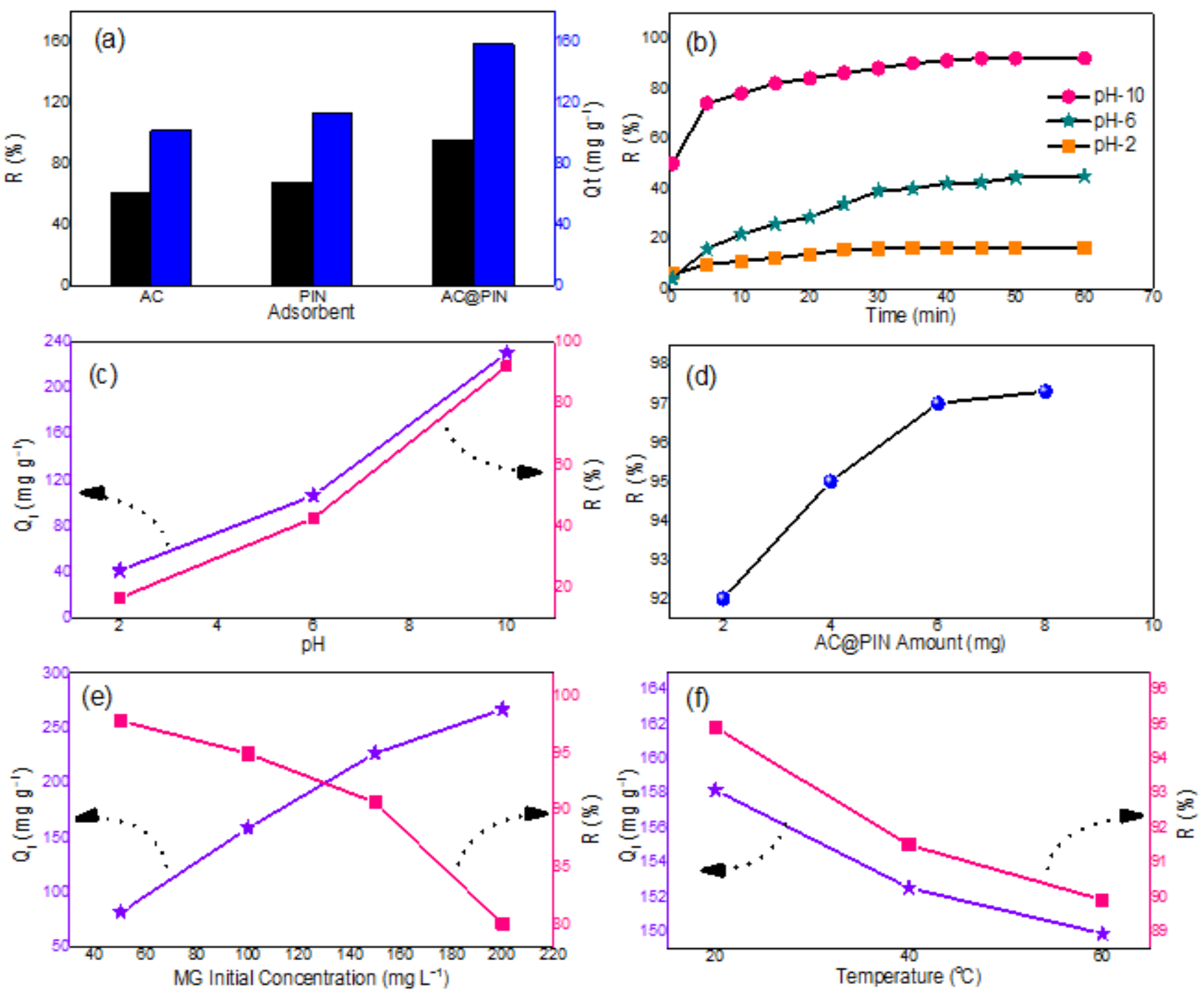

Figure 7. (a) Adsorption efficiency and capacity of AC, PIN, and AC@PIN composite, (b,c) percent removal of $\mathrm{MG}$ as a function of time and $\mathrm{pH}\left[\mathrm{Co}=50 \mathrm{mg} \mathrm{L}^{-1}\right.$; Temperature $=20^{\circ} \mathrm{C}$; $\left.\mathrm{AC} @ \mathrm{PIN}=2 \mathrm{mg}\right]$, (d) effect of AC@PIN amount on adsorption of MG $\left[\mathrm{Co}=50 \mathrm{mg} \mathrm{L}^{-1}\right.$; Temperature $=20^{\circ} \mathrm{C} ; \mathrm{pH}=10$; contact time $=60 \mathrm{~min}$ ], (e) effect of initial concentration on $\mathrm{MG}$ adsorption [Temperature $=20^{\circ} \mathrm{C}$; $\mathrm{pH}=10$; contact time $=60 \mathrm{~min} ; \mathrm{AC} @ \mathrm{PIN}=6 \mathrm{mg}$, and $(\mathbf{f})$ effect of temperature on adsorption of MG $\left[\mathrm{Co}=100 \mathrm{mg} \mathrm{L}^{-1} ; \mathrm{pH}=10\right.$; contact time $=60 \mathrm{~min} ; \mathrm{AC} @ \mathrm{PIN}=6 \mathrm{mg}$.

\subsubsection{Influence of AC@PIN Dosage}

The effect of AC@PIN dosage on the adsorption of MG was investigated in the adsorbent dosage range of 2.0 to $8.0 \mathrm{mg}$. Figure $7 \mathrm{~d}$ illustrates that the adsorption efficiency is greatly dependent on the AC@PIN amount. The percent removal of MG increased as the amount of AC@PIN was increased. This observation is better explained by the availability of large number of accessible active sites of the AC@PIN composite [1,4]. The maximum value of MG removal efficiency of about $97 \%$ was removed by $6.0 \mathrm{mg}$ AC@PIN composite. Further increase in adsorbent dosage did not show any significant increase in adsorption efficiency. This might be due to the possible overlapping of the binding sites due to aggregation of adsorbent particles under high dosage of the composite. Similar results are also reported by Abdelghani et al. [1]. They noticed similar behavior of PANI@AS composite towards Orange $\mathrm{G}$ dye adsorption. Thus, $6.0 \mathrm{mg}$ was fixed as the optimal adsorbent dosage for further experiments. 


\subsubsection{Influence of MG Concentration}

The dye concentration is another important parameter to investigate adsorption process. The influence of MG initial concentration on the adsorption uptake and removal efficiency of AC@PIN was evaluated by varying initial dye concentration from 50 to $200 \mathrm{mg} \mathrm{L}^{-1}$. As shown in Figure 7e, the adsorption capacity increased from 81.5 to $266.6 \mathrm{mg} \mathrm{g}^{-1}$ with the increase in initial MG concentration. The adsorption capacity of AC@PIN composite is low under low concentration condition of MG which is due to the weak driving force rendering less number of collisions between MG molecules. This results in low mass transfer from liquid to phase to the adsorbent surface [2]. At high initial concentration of MG, the adsorption capacity is high. This might be due to the increased collisions between MG molecules resulting in high driving force and low resistance, thus, promoting a large mass transfer from liquid to solid. The surface active sites are completely saturated with MG under high initial concentration of MG [4,32]. Moreover, the decrease in dye removal efficiency (from 97.8 to $80 \%$ ) with increase in MG concentration is clearly evident from Figure 7e. This can be attributed to the unavailability of active binding sites on AC@PIN surface. These results coincide with previous reports [2,32].

\subsubsection{Influence of Temperature}

Finally, the effect of temperature on the adsorption of MG onto AC@PIN was investigated by varying the temperature from 20 to $60^{\circ} \mathrm{C}$. Figure $7 \mathrm{f}$ illustrates the adsorption capacity and percent removal of MG by AC@PIN composite as a function of temperature. It can be clearly seen from the graph that the adsorption capacity and removal efficiency decreased with the increase in temperature. This revealed the exothermic nature of MG adsorption onto the composite. The increased kinetic energy and mobility of MG ions with the rise in temperature might have caused the reduction in adsorption $[2,32]$.

\subsubsection{Adsorption Kinetics}

The kinetic study of adsorption process is important to select the optimum operating parameters for the complete adsorption process. Kinetic study is helpful to gain information about the rate, reaction pathway, diffusion, and mass transfer mechanism of dye adsorption [4,32]. To evaluate the kinetics of MG adsorption on AC@PIN composite, pseudo-first-order and pseudo-second-order model were employed. The linear expression of pseudo-1st-order and pseudo-2nd-order kinetic models is given in Equations (3) and (4), respectively $[4,9]$.

$$
\begin{gathered}
\log \left[\mathrm{Q}_{\mathrm{e}}-\mathrm{Q}_{\mathrm{t}}\right]=\log \mathrm{Q}_{\mathrm{e}}-\left[\mathrm{k}_{1} / 2.303\right] \mathrm{t} \\
\mathrm{t} / \mathrm{Q}_{\mathrm{t}}=1 /\left[\mathrm{k}_{2} \mathrm{Q}_{\mathrm{e}}{ }^{2}\right]+\mathrm{t} / \mathrm{Q}_{\mathrm{e}}
\end{gathered}
$$

where $Q_{\mathrm{e}}\left(\mathrm{mg} \mathrm{g}^{-1}\right)$ is the adsorption capacity at equilibrium, $\mathrm{Q}_{\mathrm{t}}\left(\mathrm{mg} \mathrm{g}^{-1}\right)$ is the adsorption capacity at time $\mathrm{t}(\mathrm{min}), \mathrm{k}_{1}\left(\mathrm{~min}^{-1}\right)$ is the pseudo-1st-order rate constant, and $\mathrm{k}_{2}$ $\left(\mathrm{g} \mathrm{mg}^{-1} \mathrm{~min}^{-1}\right)$ is the pseudo-2nd-order rate constant. The kinetic models linear fitting to experimental data points of MG adsorption onto AC@PIN composites are displayed in Figure $8 \mathrm{a}, \mathrm{b}$ and the values of fitting parameters for respective models are given in Table 1. The regression coefficient $\left(\mathrm{R}^{2}\right)$ values of the pseudo-1st-order and pseudo-2nd-order model are 0.97 and 0.99 , respectively. Moreover, the experimental $Q_{e}$ value is in close agreement with the calculated $Q_{e}$ from pseudo-2nd-order model. These findings indicated that pseudo-2nd-order model is best fitted to our adsorption experimental data.

Table 1. Kinetic parameter values for the MG adsorption on AC@PIN composite.

\begin{tabular}{ccccccc}
\hline Experimental & \multicolumn{3}{c}{ Pseudo-1st-Order } & \multicolumn{3}{c}{ Pseudo-2nd-Order } \\
\hline $\begin{array}{c}\mathbf{Q}_{\mathbf{e}} \\
\left(\mathbf{m g ~ g}^{-\mathbf{1}}\right)\end{array}$ & $\begin{array}{c}\mathbf{Q}_{\mathbf{e}} \\
\left(\mathbf{m g ~ g}^{-\mathbf{1}}\right)\end{array}$ & $\begin{array}{c}\mathbf{K}_{\mathbf{1}} \\
\left(\mathbf{m i n}^{-\mathbf{1}}\right)\end{array}$ & $\mathbf{R}^{\mathbf{2}}$ & $\begin{array}{c}\mathbf{Q}_{\mathbf{e}} \\
\left(\mathbf{m g ~ g}^{-\mathbf{1}}\right)\end{array}$ & $\begin{array}{c}\mathbf{K}_{\mathbf{2}} \\
\left.\mathbf{g ~ m ~}^{\mathbf{1}} \mathbf{~ m i n}^{-\mathbf{1}}\right)\end{array}$ & $\mathbf{R}^{\mathbf{2}}$ \\
\hline 226.5 & 51.12 & -1.46 & 0.97 & 250 & 0.003 & 0.99 \\
\hline
\end{tabular}



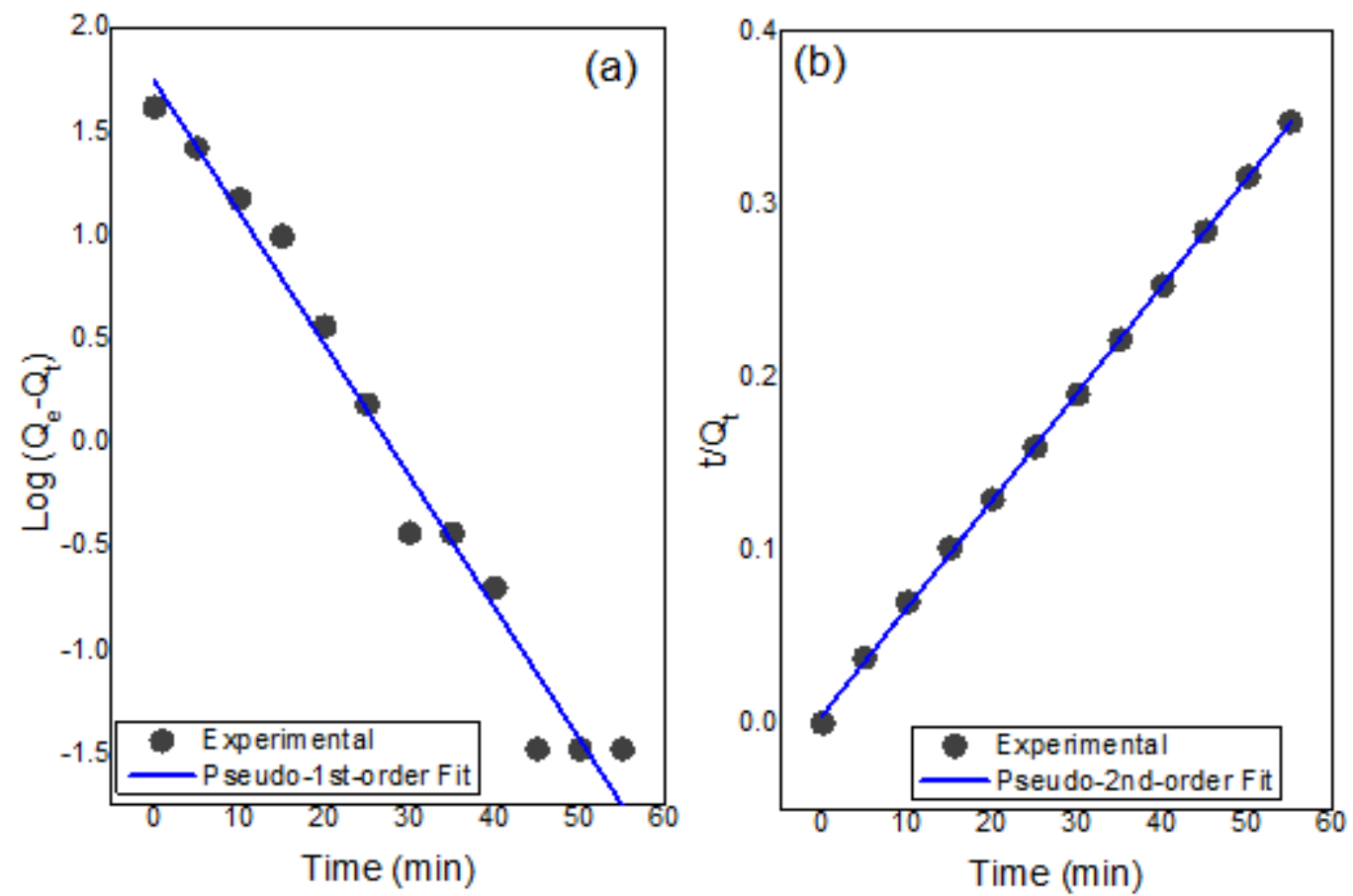

Figure 8. Plots of the (a) pseudo-1st-order, and (b) pseudo-2nd-order model for MG adsorption onto AC@PIN composite $\left[\mathrm{Co}=150 \mathrm{mg} \mathrm{L}^{-1}\right.$; Temperature $=20^{\circ} \mathrm{C}$; $\mathrm{AC} @ \mathrm{PIN}=6 \mathrm{mg}$, contact time $=60 \mathrm{~min}$, $\mathrm{pH}=10]$.

\subsubsection{Adsorption Isotherms}

The isotherm modelling is a helpful tool to understand the adsorbent surface properties, distribution of adsorbate molecules at the interface, and interaction between adsorbent and adsorbate $[1,2,46]$. Langmuir and Freundlich isotherm models are the most commonly employed adsorption isotherm models to a solid-liquid system. Langmuir isotherm model predicts the monolayer adsorption on a homogeneous adsorbent surface where finite number of active sites are present. Besides, it assumes that no interaction between adsorbed molecules occurs on the surface. The linear expression of Langmuir isotherm model is given in Equation (5) [2,32].

$$
\mathrm{Ce} / \mathrm{Q}_{\mathrm{e}}=\left[\mathrm{Ce} / \mathrm{Q}_{\mathrm{m}}\right]+1 /\left[\mathrm{K}_{\mathrm{L}} \times \mathrm{Q}_{\mathrm{m}}\right]
$$

where $\mathrm{Q}_{\mathrm{e}}\left(\mathrm{mg} \mathrm{g}^{-1}\right)$ is adsorption capacity and $\mathrm{Ce}\left(\mathrm{mg} \mathrm{L}^{-1}\right)$ is $\mathrm{MG}$ concentration in equilibrium condition. $\mathrm{K}_{\mathrm{L}}$ is Langmuir isotherm constants and it represents the affinity of active sites and $\mathrm{Q}_{\mathrm{m}}\left(\mathrm{mg} \mathrm{g}^{-1}\right)$ is the monolayer adsorption capacity.

The validity of Langmuir isotherm model is verified from the Langmuir separation factor $\left(R_{L}\right)$. $R_{L}$ is related to the favorability of the adsorption process. If $R_{L}$ value is between 0 and 1, the adsorption process is favorable, while the value of $R_{L}$ great than 1 indicates unfavorable adsorption. The following Equation (6) is used to determine $R_{L}$ [2].

$$
\mathrm{R}_{\mathrm{L}}=1 /\left[1+\mathrm{K}_{\mathrm{L}} \times \mathrm{C}_{\mathrm{o}}\right]
$$

Freundlich isotherm model predicts multilayer adsorption process on a heterogeneous surface. It assumes the possible interaction between adsorbate and adsorbent surface with the uneven distribution of active sites. The linear form of Freundlich isotherm model is in Equation (7) [2,32].

$$
\ln \mathrm{Q}_{\mathrm{e}}=\ln \mathrm{K}_{\mathrm{F}}+[1 / \mathrm{n}] \ln \mathrm{C}_{\mathrm{e}}
$$

where $\mathrm{K}_{\mathrm{F}}\left(\mathrm{mg} \mathrm{g}^{-1}\right)$ is Freundlich isotherm constant which express the extent of adsorption, $C_{e}\left(\mathrm{mg} \mathrm{L}^{-1}\right)$ is dye equilibrium concentration, $Q_{e}\left(\mathrm{mg} \mathrm{g}^{-1}\right)$ is equilibrium adsorption capacity and $n\left(\mathrm{~g} \mathrm{~L}^{-1}\right)$ is Freundlich isotherm constant which is related to the adsorption 
intensity. The linear plot of Langmuir and Freundlich isotherm models are presented in Figure 9 and parameter values are listed in Table 2.
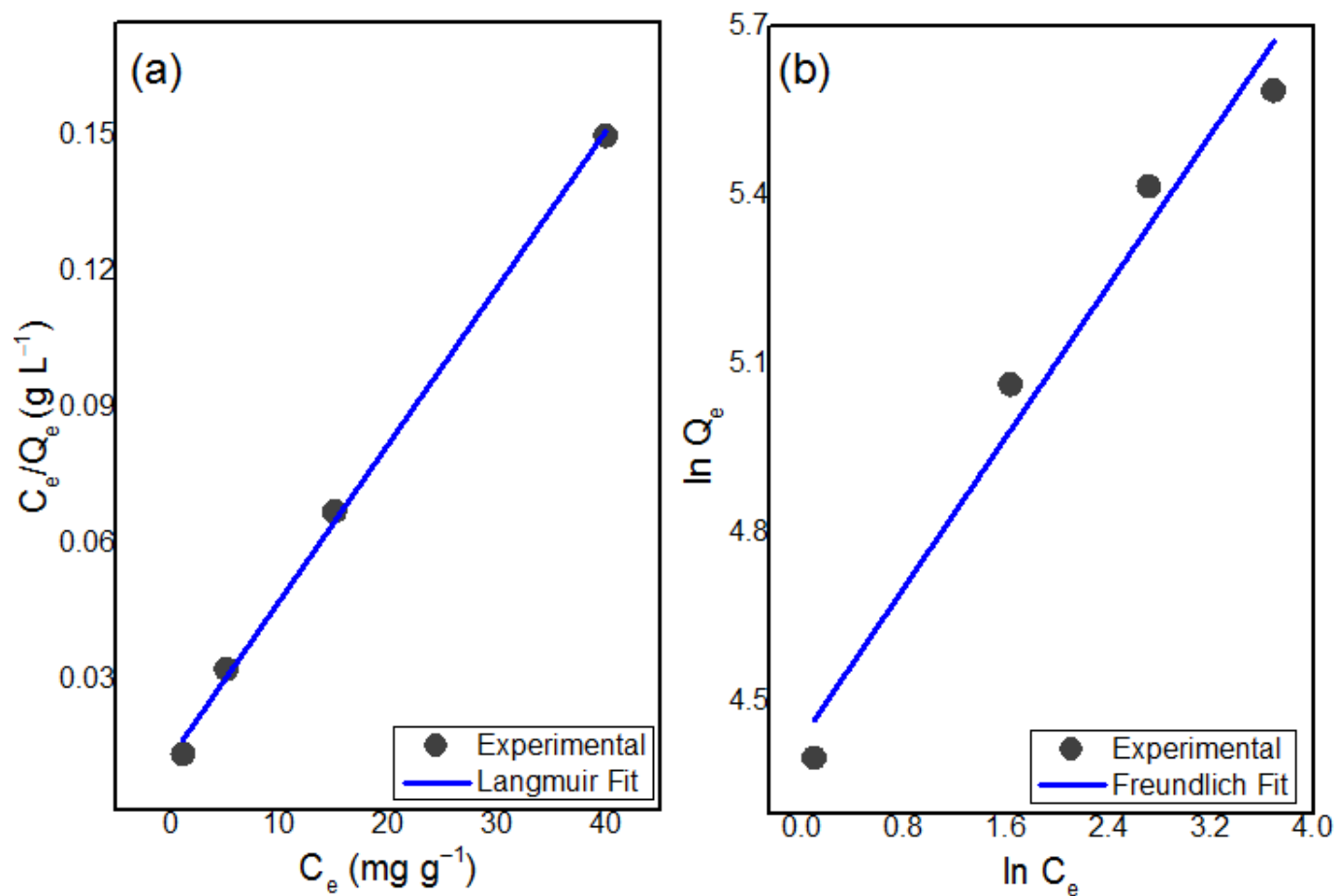

Figure 9. Isotherm model plots for MG adsorption onto AC@PIN composite (a) Langmuir and (b) Freundlich isotherms [AC@PIN =6 mg; Temperature $=20^{\circ} \mathrm{C}$; contact time $=60 \mathrm{~min} ; \mathrm{pH}=10$ ].

Table 2. Isotherm parameter values for adsorption of MG on AC@PIN composite at $20^{\circ} \mathrm{C}$.

\begin{tabular}{ccccccc}
\hline Experimental & \multicolumn{3}{c}{ Langmuir Isotherm Model } & \multicolumn{3}{c}{ Freundlich Isotherm Model } \\
\hline $\begin{array}{c}\mathbf{Q}_{\mathbf{e}} \\
\left(\mathbf{m g ~ g}^{-\mathbf{1}}\right)\end{array}$ & $\begin{array}{c}\mathbf{Q}_{\mathbf{e}} \\
\left.\mathbf{m g ~ g}^{-\mathbf{1}}\right)\end{array}$ & $\mathbf{K}_{\mathbf{L}}$ & $\mathbf{R}^{\mathbf{2}}$ & $\begin{array}{c}\mathbf{K}_{\mathbf{F}} \\
\left(\mathbf{m g ~ g}^{-\mathbf{1}}\right)\end{array}$ & $\mathbf{n}$ & $\mathbf{R}^{\mathbf{2}}$ \\
\hline 226.5 & 289.01 & 0.271 & 0.99 & 26915 & 2.9 & 0.95 \\
\hline
\end{tabular}

It can be clearly seen from Figure 9 and Table 2 that the adsorption experimental data fitted well in Langmuir isotherm model with the $\mathrm{R}^{2}$ value of 0.99 . The good correlation between experimental $Q_{\mathrm{e}}\left(226.5 \mathrm{mg} \mathrm{g}^{-1}\right)$ and calculated $\mathrm{Q}_{\mathrm{e}}\left(289.01 \mathrm{mg} \mathrm{g}^{-1}\right)$ further suggests that Langmuir isotherm model is better fitted than Freundlich model $\left(R^{2}=0.95\right)$ for the MG adsorption onto AC@PIN. The viability of Langmuir isotherm models is also confirmed from the value of $R_{L}(0.07>0)$. In addition, the value of $n(2.9>1)$ implies that MG adsorption onto AC@PIN is favorable.

\subsubsection{Thermodynamic Study}

To get the better understanding of MG adsorption on AC@PIN composite, the thermodynamic parameters including entropy change $\left(\Delta \mathrm{S}^{\circ}\right)$, enthalpy change $\left(\Delta \mathrm{H}^{\circ}\right)$, and Gibbs free energy change $\left(\Delta G^{\circ}\right)$ are computed in this study using the given Equations $(8)-(10)[9,32]$.

$$
\Delta \mathrm{G}^{\circ}=-\mathrm{RT} \ln \mathrm{K}_{\mathrm{c}}
$$

where $\mathrm{K}_{\mathrm{c}}$ is the adsorption equilibrium constant which is calculated as;

$$
\mathrm{K}_{\mathrm{c}}=\mathrm{C}_{\mathrm{ae}} / \mathrm{C}_{\mathrm{e}}
$$

where $\mathrm{C}_{\mathrm{ae}}\left(\mathrm{mg} \mathrm{L}^{-1}\right)$ is the dye equilibrium concentration at the adsorbent surface, while $\mathrm{C}_{\mathrm{e}}$ $\left(\mathrm{mg} \mathrm{L}^{-1}\right)$ is the dye equilibrium concentration in solution. 
The values of $\Delta \mathrm{H}^{\circ}$ and $\Delta \mathrm{S}^{\circ}$ of the adsorption process is estimated from slope and intercept of the plot (ln $K_{c}$ vs. 1/T) obtained through Van't Hoff Equation (10).

$$
\ln \mathrm{K}_{\mathrm{c}}=\left[-\Delta \mathrm{H}^{\circ} / \mathrm{RT}\right]+\left[\Delta \mathrm{S}^{\circ} / \mathrm{R}\right]
$$

The thermodynamic parameters were computed graphically from Figure 10a and are tabulated in Table 3. The feasibility and spontaneity of the MG adsorption on the prepared composite is clearly indicated by the negative values of $\Delta G^{\circ}$. Moreover, $\Delta G^{\circ}$ values increases as the temperature is raised from $298-328 \mathrm{~K}$. This shows that the MG adsorption is more favorable at high temperature [17,32]. Besides, $\Delta \mathrm{H}^{\circ}$ value is negative and is less than $40 \mathrm{~kJ} \mathrm{~mol}^{-1}$. This revealed the exothermic and physical adsorption of MG on the AC@PIN. The negative value of $\Delta S^{\circ}$ confirmed that no significant changes occur in the internal structure of AC@PIN [9,32].
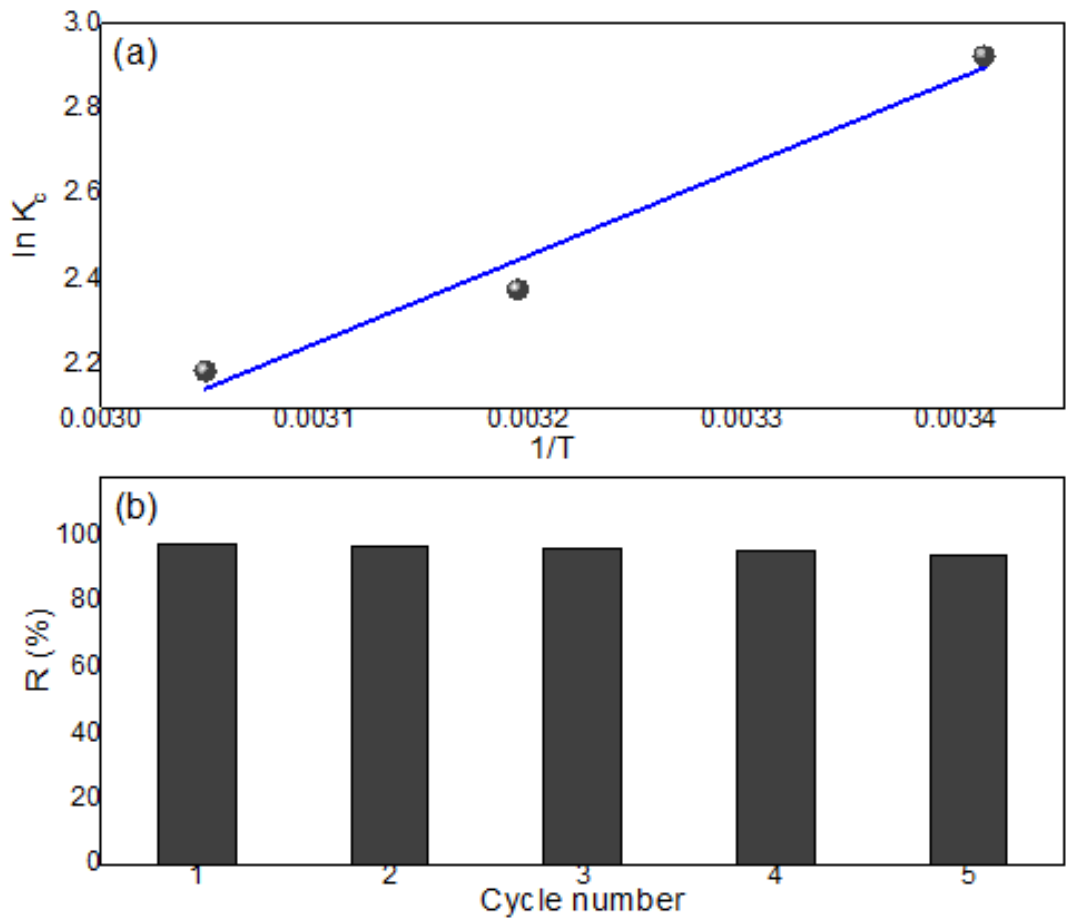

Figure 10. (a) Van't Hoff plot and (b) reusability test of AC@PIN composite.

Table 3. Calculated values of thermodynamic parameters.

\begin{tabular}{|c|c|c|c|c|}
\hline $\begin{array}{c}\text { Temperature } \\
\text { (K) }\end{array}$ & $\begin{array}{c}\Delta \mathrm{G}^{\circ} \\
\left(\mathrm{kJ} \mathrm{mol}^{-1}\right)\end{array}$ & $\begin{array}{c}\Delta \mathrm{H}^{\circ} \\
\left(\mathrm{kJ} \mathrm{mol}^{-1}\right)\end{array}$ & $\begin{array}{c}\Delta S^{\circ} \\
\left(\mathrm{kJ} \mathrm{mol}^{-1} \mathrm{~K}^{-1}\right)\end{array}$ & $\mathbf{R}^{2}$ \\
\hline 293 & -27.23 & -17.15 & -0.034 & 0.95 \\
\hline 313 & -27.92 & & & \\
\hline 328 & -28.43 & & & \\
\hline
\end{tabular}

\subsubsection{Reusability Study}

The practical implementation of the prepared adsorbent is assessed by the reusability test. Therefore, we subjected the AC@PIN to desorption-adsorption for five cycles. From Figure 10b, it is evident that the prepared AC@PIN composite has excellent regeneration capacity even after five desorption-adsorption cycles. The relatively small decrease in the removal efficiency from $97.8 \%$ (1st cycle) to $94.4 \%$ (5th cycle) is observed due to the incomplete desorption of AC@PIN [4]. 


\subsubsection{Probable Mechanism of Adsorption}

The adsorption process is majorly dependent on the nature of adsorbate and surface chemistry of adsorbent. The proposed mechanism of MG adsorption onto AC@PIN is presented in Scheme 3. It can be proposed that the MG adsorption onto AC@PIN involves $\pi-\pi$ interactions, electrostatic interactions, and hydrogen bonding. From the FTIR results, it is clear that the surface of AC@PIN composite is negatively charged due to the presence of $\mathrm{ClO}_{4}{ }^{-}, \mathrm{CH}_{3}\left(\mathrm{CH}_{2}\right)_{10} \mathrm{SO}_{3}{ }^{-}, \mathrm{HPO}_{3}{ }^{-}, \mathrm{C}_{6} \mathrm{H}_{5} \mathrm{OH}$, and $\mathrm{COOH}$ functional groups. At $\mathrm{pH}=10$, greater than $\mathrm{pH}_{\mathrm{PZC}}$, it is expected that the electrostatic interaction is more dominant between negatively charged species of AC@PIN and positively charged nitrogen species of MG in solution. Moreover, the hydrogen bonding between surface hydrogen containing groups and $\mathrm{N}$ atom of MG dyes as well as the $\pi-\pi$ interaction between $\pi$-electrons of the benzene rings in AC@PIN and MG also plays a dominant role.

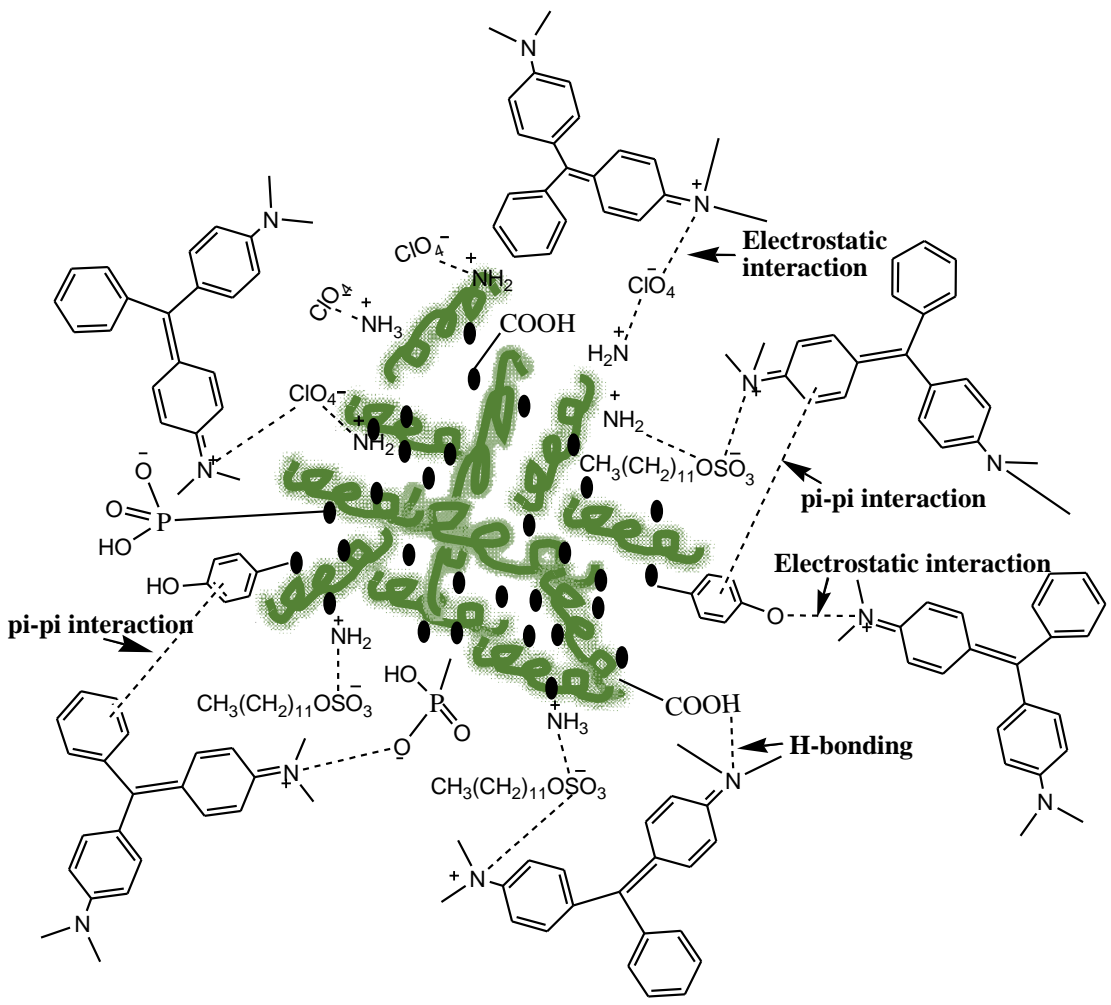

Scheme 3. Possible adsorption mechanism of MG onto AC@PIN.

Table 4 compares various polymer-based adsorbents reported previously for the removal of MG. The $Q_{e}\left(226.5 \mathrm{mg} \mathrm{g}^{-1}\right)$ value of AC@PIN composite prepared in the current work is comparable to other adsorbents. Besides, AC@PIN is relatively more efficient, eco-friendly, and easy to prepare in bulk amounts compared to the corresponding ones. 
Table 4. Comparison of adsorption properties of various polymer based adsorbents towards Malachite Green dye.

\begin{tabular}{|c|c|c|c|c|c|c|c|}
\hline Adsorbents & $\begin{array}{c}\mathrm{Q}_{\mathrm{e}} \\
\left(\mathrm{mg} \mathrm{g}^{-1}\right)\end{array}$ & $\begin{array}{l}\text { Equilibrium } \\
\text { Time } \\
\text { (min) }\end{array}$ & $\begin{array}{l}\text { Adsorbent } \\
\text { Dosage } \\
\text { (g) }\end{array}$ & Kinetic Study & $\begin{array}{l}\text { Isotherm } \\
\text { Study }\end{array}$ & $\begin{array}{l}\text { Thermodynamic } \\
\text { Study }\end{array}$ & Ref \\
\hline $\mathrm{PVA} / \mathrm{CMC} / \mathrm{SA} / \mathrm{ZSM}^{\mathrm{a}}$ & 5.95 & 220 & 5.0 & $\begin{array}{l}\text { Pseudo-2nd- } \\
\text { order }\end{array}$ & Freundlich & - & [2] \\
\hline $\mathrm{Fe}_{2} \mathrm{O}_{3} @ \mathrm{PANI}$ & 240.0 & 240 & 0.01 & $\begin{array}{l}\text { Pseudo-2nd- } \\
\text { order }\end{array}$ & Langmuir & exothermic & [47] \\
\hline PANI-nickel ferrite & 4.09 & 210 & 5.0 & $\begin{array}{l}\text { Pseudo-2nd- } \\
\text { order }\end{array}$ & Langmuir & - & [48] \\
\hline $\begin{array}{l}\text { Poly(methyl methacry- } \\
\text { late)/graphene } \\
\text { oxide- }-\mathrm{Fe}_{3} \mathrm{O}\end{array}$ & 3.5 & 35 & 0.005 & $\begin{array}{l}\text { Pseudo-2nd- } \\
\text { order }\end{array}$ & - & exothermic & [49] \\
\hline $\begin{array}{c}\text { Kappa-carrageenan-g- } \\
\text { polyacrylic } \\
\text { acid } / \mathrm{TiO}_{2}-\mathrm{NH}_{2}\end{array}$ & 666.66 & 180 & 0.05 & $\begin{array}{l}\text { Pseudo-2nd- } \\
\text { order }\end{array}$ & Langmuir & exothermic & [50] \\
\hline $\begin{array}{c}\text { Poly(vinyl } \\
\text { alcohol)-chitosan }\end{array}$ & 380.6 & 540 & 0.1 & $\begin{array}{l}\text { Pseudo-2nd- } \\
\text { order }\end{array}$ & Freundlich & endothermic & [51] \\
\hline AC@PIN & 226.5 & 60 & 0.006 & $\begin{array}{l}\text { Pseudo-2nd- } \\
\text { order }\end{array}$ & Langmuir & exothermic & $\begin{array}{l}\text { This } \\
\text { work }\end{array}$ \\
\hline
\end{tabular}

${ }^{\mathrm{a}}=$ polyvinyl alcohol-carboxymethyl cellulose-sodium alginate zeolite-5.

\section{Conclusions}

AC@PIN composites were synthesized via a facile and convenient in situ chemical polymerization method, and the same was employed for the adsorptive removal of Malachite Green dye from aqueous solution. The prepared composites were characterized by FTIR, SEM, XRD, EDX, and UV-Vis spectroscopy. The process variables $(\mathrm{pH}$, contact time, AC@PIN amount, Malachite Green initial concentration, and temperature) were found to have a significant influence on the MG adsorption on the AC@PIN. The maximum adsorption capacity of $226.5 \mathrm{mg} \mathrm{g}^{-1}$ and $97.3 \%$ removal efficiency was attained at $\mathrm{pH}=10$ in the contact time of $60 \mathrm{~min}$ at temperature $20^{\circ} \mathrm{C}$. Moreover, the pseudo-2nd-order kinetic model and Langmuir isotherm model fitted well to the MG adsorption on the prepared composite. In addition, the adsorption of dye was found to be exothermic in nature. Though, the adsorption capacity is not much higher, still the prepared AC@PIN composite is comparatively more efficient as it can remove $97.3 \%$ of the dye from aqueous system by attain equilibrium in relatively less time. Besides, it is a novel and an eco-friendly adsorbent which can be prepared at low cost in large amount by a simple and convenient one-pot chemical oxidation method. Overall, the promising adsorption efficiency makes the prepared AC@PIN composite as a potential contender in the list of available adsorbents for the removal of dye from wastewater.

Author Contributions: Conceptualization, B.B.; methodology, B.B. and S.I.; software, B.B., S.I., R.A.Q. and M.S.K.; validation, B.B. and R.K.; formal analysis, B.B., S.I., R.A.Q. and M.S.K.; investigation, B.B., S.I. and R.K.; resources, B.B., R.K. and M.S.K.; writing-original draft preparation, B.B. and S.I.; writing - review and editing, R.K. and K.H.M. All authors have read and agreed to the published version of the manuscript.

Institutional Review Board Statement: Not Applicable.

Informed Consent Statement: Not Applicable.

Data Availability Statement: The data presented in this study are available on request from the corresponding authors.

Acknowledgments: The authors would like to acknowledge the financial support of Taif University Researchers Supporting Project number (TURSP-2020/162), Taif University, Taif, Saudi Arabia. 
Conflicts of Interest: The authors declare no conflict of interest. The funders had no role in the design of the study; in the collection, analyses, or interpretation of data; in the writing of the manuscript, or in the decision to publish the results.

\section{References}

1. Abdelghani, H.; Abdelilah, E.; Nouh, A.; Mohamed, L.; Abdelaziz, A.A.; Rajae, L.; Abdallah, A. Elaboration of novel polyaniline@almond shell biocomposite for effective removal of hexavalent chromium ions and orange $\mathrm{G}$ dye from aqueous solutions. Environ. Sci. Pollut. Res. 2020, 27, 15245-15258.

2. Sabarish, R.; Jasila, K.; Aswathy, J.; Jyotishkumar, P.; Suchart, S. An efficient removal of malachite green dye from aqueous environment using ZSM-5 zeolite/polyvinyl alcohol/carboxymethyl cellulose/sodium alginate bio composite. J. Polym. Environ. 2021, 29, 2126-2139.

3. Shilpi, A.; Inderjeet, T.; Vinod, K.G.; Fariba, G.; Ahmad, N.G.; Omid, M. Synthesis and characteristics of polyaniline/zirconium oxide conductive nanocomposite for dye adsorption application. J. Mol. Liq. 2016, 218, 494-498. [CrossRef]

4. Sabarish, R.; Jasila, K.; Aswathy, J.; Jyotishkumar, P.; Suchart, S. Removal of anionic dye congo red from aqueous environment using polyvinyl alcohol/sodium alginate/ZSM-5 zeolite membrane. Sci. Rep. 2020, 10, 15452-15466.

5. Sudhindra, P.; Radhika, A.K.; Libi, T. Polyaniline-multiwalled carbon nanotubes (PANI-MWCNTs) composite revisited: An efficient and reusable material for methyl orange dye removal. Diam. Relat. Mater. 2021, 117, 108455-108460. [CrossRef]

6. Khaoula, L.; Sonia, F.; Mostafa, S.; Julia, G.A. Adsorption of an anionic dye (Congo red) from aqueous solutions by pine bark. Sci. Rep. 2019, 9, 16530-16540.

7. Mudassir, H.; MdMamoon, R.; Muhammad, M.H.; Mohammed, K.A.M.; Muhammad, A.; Mohd, D.; Moonyong, L.; Atef, E.J.; Narendra, K. Fabrication of polyaniline/activated carbon composite and its testing for methyl orange removal: Optimization, equilibrium, isotherm, and kinetic study. Polym. Test. 2019, 77, 105909-105917. [CrossRef]

8. Sarojini, G.; Babu, S.V.; Rajamohan, N.; Rajasimman, M. Performance evaluation of polymer-marine biomass based bionanocomposite for the adsorptive removal of malachite green from synthetic wastewater. Environ. Res. 2022, 204, 112132. [CrossRef] [PubMed]

9. Saima, N.; Haq, N.B.; Munawar, I.; Fida, H.; Fazli, M.S. Chitosan, starch, polyaniline and polypyrrole biocomposite with sugarcane bagasse for the efficient removal of acid black dye. Inter. J. Biol. Macromol. 2020, 147, 439-452. [CrossRef]

10. Cai, Z.; Yang, G. Synthesis of polyindole and its evaluation for Li-ion battery applications. Synth. Met. 2010, 160, 1902-1905. [CrossRef]

11. Mudila, H.; Prasher, P.; Kumar, M.; Kumar, A.; Zaidi, M.G.H.; Kumar, A. Critical analysis of polyindole and its composites in supercapacitor application. Mater. Renew. Sustain. Energy 2019, 8, 9. [CrossRef]

12. Zhijiang, C.; Xianyou, S.; Qing, Z.; Tingting, Z. Electrospun polyindole nanofibers as a nano-adsorbent for heavy metal ions adsorption for wastewater treatment. Fibers Polym. 2017, 18, 502-513. [CrossRef]

13. Cai, Z.; Jia, J.; Zhang, Q.; Yang, H. Preparation of amidoxime surface-functionalized polyindole (ASFPI) nanofibers for Pb(II) and Cd(II) adsorption from aqueous solutions. RSC Adv. 2015, 5, 82310-82323. [CrossRef]

14. Cai, Z.; Song, X.; Zhang, Q.; Liu, Y. Amidoxime surface modification of polyindole nanofiber membrane for effective removal of $\mathrm{Cr}(\mathrm{VI})$ from aqueous solution. J. Mater. Sc. 2017, 52, 5417-5434.

15. Halit, Y.; Serife, T.; Cengis, S. Preparation of polyacrylonitrile/polyindole conducting polymer composite and its use for solid phase extraction of copper in a certified reference material. Spectrochim. Part A Molecul. Biomolecul. Spect. 2021, 244, 118826-118834. [CrossRef]

16. Dedhila, D.; Baiju, V.; Deepa, J.P.; Raveendran, R. The novel polyindole base $\mathrm{ZnO} / \mathrm{MgO}$ nanocomposite adsorbent for the removal of heavy metal ions from industrial effluents. Nanosyst. Phys. Chem. Math. 2020, 11, 666-671. [CrossRef]

17. Venkata, S.M.; Hsin-Yu, W.; Jet-Chau, W.; Yuvaraja, G.; Zhong, T.; Guda, M.R.; Jarem, R.G. Anionic congo red dye removal from aqueous medium using Turkey tail (Trametes versicolor) fungal biomass: Adsorption kinetic, isotherms, thermodynamics, reusability, and characterization. J. Dispers. Sci. Technol. 2021, 42, 1785-1798. [CrossRef]

18. Cai, Z.-J.; Zhang, Q.; Song, X.-Y. Improved electrochemical performance of polyindole/carbon nanotubes composite as electrode material for supercapacitors. Electron. Mater. Lett. 2016, 12, 830-840. [CrossRef]

19. Goel, S.; Mazumdar, N.A.; Gupta, A. Fabrication of polyindene and polyindole nanostructures. Appl. Surf. Sci. 2010, 256, 4426-4433. [CrossRef]

20. Abdollahi-Alibeik, M.; Poorirani, S. Perchloric acid-doped polyaniline as an efficient and reusable catalyst for the synthesis of 2-subsituted benzothiazoles. Phosphorus Sulfur Silicon 2009, 184, 3182-3190. [CrossRef]

21. Eraldemir, O.; Sari, B.; Gok, A.; Ibrahim, U.H. Synthesis and characterization of polyindole/poly(vinyl acetate) conducting composites. J. Macromol. Sci. Part A 2008, 45, 205-211. [CrossRef]

22. Phasuksom, K.; Sirivat, A. Synthesis of nano-sized polyindole via emulsion polymerization and doping. Synth. Met. 2016, 219, 142-153. [CrossRef]

23. Anisuzzaman, S.M.; Joseph, C.G.; Daud, W.M.A.B.W.; Krishnaiah, D.; Yee, H.S. Preparation and characterization of activated carbon rom Typhaorientalis leaves. Int. J. Ind. Chem. 2015, 6, 9-21. [CrossRef]

24. Gao, X.; Wu, L.; Wan, W.; Xu, Q.; Li, Z. Preparation of activated carbons from walnut shell by fast activation with $\mathrm{H}_{3} \mathrm{PO}_{4}$ : Influence of fluidization of particles. Int. J. Chem. React. Eng. 2017, 16, 20170074-20170083. [CrossRef] 
25. Yakout, S.M.; EI-Deen, G.S. Characterization of activated carbon prepared by phosphoric acid activation of olive stones. Arab. J. Chem. 2016, 9, S1155-S1162. [CrossRef]

26. Saptarshi, D.; Pallab, B.; Goutam, H.; Sumanta, S.; Das, C.K. Transition Metal-Doped Polyaniline/Single Walled Carbon Nanotubes Nanocomposites: Efficient Electrode Material for High Performance Supercapacitor. ACS Sustain. Chem. Eng. 2014, 2, $1114-11127$.

27. Leela, J.; Arun, K.S.; Rajiv, P. Polyindole/carboxylated-multiwall carbon nanotube composites produced by in-situ and interfacial polymerization. Mater. Chem. Phys. 2012, 135, 80-87.

28. Karim, M.R.; Lee, C.J.; Lee, M.S. Synthesis and characterization of conducting polyaniline-activated carbon nanocomposites. $J$. Appl. Polym. Sci. 2007, 103, 1973-1977. [CrossRef]

29. Patil, D.S.; Pawar, S.A.; Devan, R.S.; Ma, Y.R.; Bae, W.R.; Kim, J.H.; Patil, P.S. Improved electrochemical performance of activated carbon/polyaniline composite electrode. Mater. Lett. 2014, 117, 248-251. [CrossRef]

30. Olad, A.; Gharekhani, H. Preparation and Electrochemical investigation of the polyaniline/activated carbon nanocomposite for supercapacitor applications. Prog. Organ. Coat. 2015, 81, 19-26. [CrossRef]

31. Lopamudra, G.; Papita, D.; Avijit, B.; Chiranjib, B. Treatment of malachite green dye containing solution using bio-degradable sodium alginate/ $\mathrm{NaOH}$ treated activated carbon sugarcane bagasse charcoal beads: Batch, optimization using response surface methodology continuous fixed bed column study. J. Environ. Manag. 2020, 276, 111272-111283.

32. Nirva, P.R.; Prapti, U.S.; Nisha, K.S. Nanoparticles loaded biopolymer as effective adsorbent for adsorptive removal of malachite green from aqueous solution. Water Conserv. Sci. Eng. 2016, 1, 169-181.

33. Khamngoen, K.; Paradee, N.; Sirivat, A. Chemical oxidation polymerization and Characterization of polyortho-anisidinenanoparticles. J. Polym. Res. 2016, 23, 172. [CrossRef]

34. Palaniappan, S.; Srinivas, P. Nano fiber polyaniline containing long chain and small molecule dopants and carbon composites for supercapacitor. Electrochim. Acta 2013, 95, 251-259.

35. Zengin, H.; Kalaci, G. Synthesis and characterization of polyaniline/activated Carbon composites and preparation of conductive films. Mater. Chem. Phys. 2010, 120, 46-53. [CrossRef]

36. Khalil, H.P.S.; Jawaid, M.; Firoozian, P.; Rashid, U.; Islam, A.; Akil, H.M. Activated carbon from various agricultural wastes by chemical activation with $\mathrm{KOH}$ : Preparation and characterization. J. Biobased Mater. Bioenergy 2013, 7, 708-714. [CrossRef]

37. Xu, J.; Chen, L.; Qu, H.; Jiao, Y.; Xie, J.; Xing, G. Preparation and characterization of activated caron from reedy grass leaves by chemical activation with H3PO4. Appl. Surf. Sci. 2014, 320, 674-680. [CrossRef]

38. Zhou, Q.; Zhu, D.; Ma, X.; Xu, J.; Zhou, W.; Zhao, F. High-performance Capacitive behavior of layered reduce graphene oxide and polyindole nanocomposite materials. RSC Adv. 2016, 6, 29840-29847. [CrossRef]

39. Ramesan, M.T. Fabrication and characterization of conducting nanomaterials composed of copper sulfide and polyindole. Polym. Compos. 2012, 33, 2169-2176. [CrossRef]

40. Majumder, M.; Choudhary, R.B.; Koiry, S.P.; Thakur, A.K.; Kumar, U. Gravimetric and volumetric capacitive performance of polyindole/carbon black/MoS2 hybrid electrode material for supercapacitor applications. Electrochim. Acta 2017, 248, 98-111. [CrossRef]

41. Jayakrishnan, K.; Joseph, A.; Bhattathiripad, J.; Ramesan, M.T.; Chandrasekharan, K.; Narendran, N.S. Reverse saturable absorption studies in polymerized indole-Effect of polymerization in the phenomenal enhancement of third order optical nonlinearity. Optic. Mater. 2016, 54, 252-261. [CrossRef]

42. Mishra, R.; Nirala, N.R.; Pandey, R.K.; Ojha, R.P.; Prakash, R. Homogeneous Dispersion of MoS2 Nanosheets in Polyindole Matrix at Air-Water interface Assisted by Langmuir Technique. Langmuir 2017, 33, 13572-13580. [CrossRef]

43. Joshi, L.; Prakash, R. One-pot synthesis of polyindole-Au nanocomposites and its nanoscale electrical properties. Mater. Lett. 2011, 65, 3016-3019. [CrossRef]

44. Mike, T.; Xingping, W.; Ifra, M.; Pan, D.; Shengyuan, Y.; Meifang, Z. Green approach to fabricate polyindole composite nanofibers for energy and sensor applications. Mater. Lett. 2017, 209, 400-403.

45. Vighnesha, K.M.; Sangeetha, D.N.; Selvakumar, M. Synthesis and characterization of activated carbon/conducting polymer composite electrode for supercapacitor applications. J. Mater. Sci. Mater. Electron. 2018, 29, 914-921. [CrossRef]

46. Rahmat, A.; Tahira, M.; Salah, U.D.; Abdul, N.; Madeeha, A.; Muhammad, F. Efficient removal of hazardous malachite green dye from aqueous solutions using $\mathrm{H} 2 \mathrm{O} 2$ modified activated carbon as potential low-cost adsorbent: Kinetic, equillibrium, and thermodynamic studies. Desalin. Water Treat. 2019, 151, 167-182.

47. Mahto, T.K.; Chowdhuri, A.R.; Sahu, S.K. Polyaniline-functionalized magnetic nanoparticles for the removal of toxic dye from wastewate. J. Appl. Poly. Sci. 2014, 131, 1-9. [CrossRef]

48. Patil, M.R.; Shrivastava, V.S. Adsorption of malachite green by polyaniline-ferrite magnetic nanocomposite: An isotherm and kinetic study. Appl. Nanosci. 2015, 5, 809-816. [CrossRef]

49. Rajabi, M.; Mahanpoor, K.; Moradi, O. Preparation of PMMA/GO and PMMA/GO-Fe ${ }_{3} \mathrm{O}_{4}$ nanocomposites for malachite green dye adsorption: Kinetic and thermodynamic studies. Compos. Part B Eng. 2019, 167, 544-555. [CrossRef]

50. Pourjavadi, A.; Doulabi, M.; Doroudian, M. Adsorption characteristics of malachite green dye onto novel kappa-carrageenan-gpolyacrylic acid $/ \mathrm{TiO}_{2}-\mathrm{NH}_{2}$ hydrogel nanocomposite. J. Iran. Chem. Soc. 2014, 11, 1057-1065. [CrossRef]

51. Li, X.; Li, Y.; Zhang, S.; Ye, Z. Preparation and characterization of new foam adsorbents of poly(vinyl alcohol)/chitosan composites and their removal for dye and heavy metal from aqueous solution. Chem. Eng. J. 2012, 183, 88-97. [CrossRef] 